\title{
Sex and Gender Diversity in Southeast Asia
}

\author{
Douglas Sanders
}

Emeritus Faculty of Law University of British Columbia

Email: sanders_gwb@yahoo.ca

\begin{abstract}
The United Nations human rights system has recognized rights of lesbian, gay, bisexual, transgender and intersex individuals (LGBTI), with key decisions in 2011 and 2016. To what extent are the rights of these groupings respected in Southeast Asia? The visibility of LGBTI is low in Southeast Asia and government attitudes vary. Criminal laws, both secular and Sharia, in some jurisdictions, have prohibitions, but active enforcement is rare. Discrimination in employment is prohibited by law in Thailand and in local laws in the Philippines. Change of legal 'sex' for transgender individuals is sometimes possible. Legal recognition of same-sex relationships has been proposed in Thailand and the Philippines, but not yet enacted. Marriage has been opened to same-sex couples in neighboring Taiwan. Laws on adoption and surrogacy generally exclude same-sex couples. So-called 'normalizing surgery' on intersex babies needs to be deferred to the child's maturity, to protect their health and rights.
\end{abstract}

Keywords: Sexual Orientation, Gender Identity, LGBTI, Transgender, Trans, Criminal law, Sharia law, discrimination, marriage, adoption, intersex.

\section{INTRODUCTION}

The first recognition of LGBTI human rights by a 'political' body within the United Nations' system came in a 2011 resolution of the Human Rights Council condemning violence and discrimination against such people. There followed two studies by the $U N$ High Commissioner for Human Rights. Next a new UN advocacy campaign was launched, identifying lesbian women, gay men, bisexuals and transgender people, as well as intersex individuals as "Born Free and Equal", using the phrase from the opening section of the 1948 Universal Declaration of Human Rights. ${ }^{1}$ A set of imaginative videos was produced, for educational use in the campaign. One copied the lavish style of Bollywood musicals to sell its message in India. The UN Development

1 Born Free and Equal: Sexual Orientation, Gender Identity and Sex Characteristics in International Human Rights Law Second Edition, by United Nations (2019). The UN usage of 'LGBTI' is generally followed in this article. 
Program began a multi-year program titled Being LGBT in Asia. The UNDP convened national consultations with activists and community representatives in eight Asian states, always with some level of state support. Reports were published on LGBTI experience in Cambodia, China, Indonesia, Mongolia, Nepal, Philippines, Thailand and Vietnam. In 2016 the $\boldsymbol{U N}$ appointed an independent expert for the ongoing assessment of issues and developments on LGBTI rights. The mandate for the independent expert was renewed for a second term in 2019. These achievements flowed from years of LGBTI activism, plus the pioneering work by Amnesty International and Human Rights Watch as well as domestic reforms in many countries. Of course, the issues still divide States in the debates at the United Nations and, to a lesser extent, in regional human rights systems in Europe and the Americas.

There had been earlier specific advances in the 'expert' parts of the $U N$ system. In 1994, the $U \boldsymbol{N}$ Human Rights Committee, established to monitor state compliance with the International Covenant on Civil and Political Rights, ruled that laws criminalizing private consensual same-sex acts between adults were in violation of the provisions on privacy and equality in the Covenant. ${ }^{2}$ Since 2002 the mandate of the $\boldsymbol{U N}$ Special Rapporteur on Extrajudicial, Summary and Arbitrary Executions had called for the assessment of incidents where sexual orientation and gender identity were factors. The 2004 report of the Special Rapporteur on the Right to Health dealt in detail with sexual orientation and gender identity issues. These developments were in what are described as the 'expert' bodies of the United Nations system and did not necessarily represent the views of a majority of $\boldsymbol{U N}$ member states.

There has been strong support in the executive or administrative agencies of the United Nations, notably by a series of the individuals serving as High Commissioner for Human Rights. In 2010 there was international publicity about 14-year prison sentences imposed in Malawi after an 'engagement' celebration between a transgender woman and a gay man, seen as a 'same-sex marriage'. $U N$ Secretary General Ban Kimoon personally visited the country and intervened with Malawi president Mutharika, who quickly issued a pardon and the two were released. ${ }^{3}$ In a speech in San Francisco on June 26, 2015, Ban Ki-moon recounted the story of securing the pardon and, in the same speech, praised the US Supreme Court decision on same-sex marriage which had just been made public. He said he felt "enormous pride in the fact that I have been the first UN Secretary-General to push hard for equal rights and respect for LGBT people

2 In 1994, in Toonen v Australia, the Human Rights Committee ruled against a colonial era criminal law, still in force in the state of Tasmania, on grounds of privacy and equality. After some delay, the offending law was repealed by the state legislative body.

3 Ashley Currier \& Julie Moreau, "Understanding Same-Sex Marriage Debates in Malawi and South Africa” in Bronwyn Winter, Maxime Forest \& Réjane Sénac, eds, Global Perspectives on Same-Sex Marriage (Palgrave Macmillan, 2018) 81; Hakeem Onapajo \& Christopher Isike, "The Global Politics of Gay Rights: The Straining Relations between the West and Africa” (2016) 6:1 Journal of Global Analysis 21-45; Mark Gevisser, The Pink Line: The World's Queer Frontiers, main edition ed (UK: Profile Books, 2020). 
around the world." The next UN Secretary General, Antonio Guterres, continued strong support for LGBTI rights.

It is important to remember that the 2011 decision of the Human Rights Council was the first in a 'political' body, where voting was by representatives of $U \boldsymbol{N}$ member states, not analysis by 'independent experts'. At the time of writing, three such resolutions have been passed in the Council and been accepted by the General Assembly.

This paper tries to assess the extent to which the human rights of LGBTI people are recognized or violated in Southeast Asia. There is first a need to understand the invisibility that still characterizes the lives of most LGBTI individuals in Southeast Asia, as well as to comment on governmental and societal attitudes. The article will then turn to the various secular criminal laws that address same-sex and transgender activities in some states. As well, the paper will describe the relevant Islamic Sharia religiously based laws which apply to Muslims in parts of the region. A separate section will deal with the actual enforcement of these two sets of laws in Southeast Asia. The article will continue with a discussion of anti-discrimination laws, legal recognition of same-sex relationships, transgender rights and issues affecting intersex individuals. While the focus is Southeast Asia, references to developments in other parts of Asia and the world will supplement the analysis.

\section{VISIBILITY}

In order to avoid stigma and discrimination, individuals hide their sexual orientation and gender identity. This is surprisingly easy to do in most settings. The standard expression is that they choose to stay 'in the closet'. Most gays, lesbians, bisexual and transgender individuals are not 'out' to their birth families, or to work colleagues or in public life. This is a standard strategy in all parts of the world, used to avoid stigmatization and discrimination. Racial minorities and women, two other equality seeking groups, do not have this strategic option in their attempts to avoid discrimination.

There are recurring stories of state and non-state censorship of media, keeping LGBTI out of sight. Any 'positive images' of same sex relationships get clipped in Singapore. Films with LGBTI content get censored or banned in China and Malaysia. Government agencies in Taiwan, in sharp contrast, have gotten praise from filmmaker Barney Cheung for "financially and consistently" supporting LGBTI themed film production. $^{5}$

United Nations, Born Free and Equal, Fact Sheet: Intersex (2015).

Anna Leach, "Why is Taiwan the best place to be gay in Asia?", GayStarNews (12 November 2012), online: 〈https://www.gaystarnews.com/article/why-taiwan-best-place-be-gay-asia121112/>. 
The sole prominent 'out' regional entertainment figure in Asia seems to be Denise Ho from Hong Kong, a Cantopop singer, actress and activist, who has performed regionally and internationally. She was refused entry to Malaysia for a concert in 2018. She had performed there in 2006, before publicly identifying as lesbian. ${ }^{6}$ In three countries there are transgender women who are entertainment figures with high national popularity - China, Indonesia and Korea - but with no regional or international following. Each are transgender, the most visible of the LGBTI categories. ${ }^{7}$ The popular Korean boy bands may be teasingly androgenous, but only one has identified as gay. Almost all lesbian, gay, bisexual and transgender entertainment role models for Asian youth are westerners, making it easy for opponents to label homosexuality as non-Asian.

There is positive change, at least in some places. In 2016 saw two 'out' politicians gain elected political office in Asia, a gay man in the Legislative Council in the Hong Kong SAR and a transgender woman in the Philippines House of Representatives. The 2019 Thai election, for the first time, had 'out' candidates. Four were elected, all members of a large opposition party.' 2019 also saw the election of the first 'out' national legislator in Japan, again for an opposition party. ${ }^{10}$

Public 'pride' parades, in which LGBTI and supporters proclaim their existence with a colorful public march - or other similarly visible public events - are held annually in Cambodia, Hong Kong, India, Japan, Korea, Myanmar, Nepal, Philippines,

6 Denise Ho has a packed Wikipedia entry, detailing her career and LGBTI activism. See, as well, Rachel Mok, "Life as a rainbow: Can't-pop singer Denise Ho on coming out", South China Morning Post, August 18, 2013; "Hong Kong gay pop star: Malaysia show dropped over LGBT support”, Reuters, February 17, 2018. She is blocked from mainland China for her political activity in Hong Kong. Her regional success may be based on the various widely dispersed Chinese populations in much of Asia. A documentary "Denise Ho: Becoming the Song" was reviewed in the New York Times in 2020: Lovia Gyarkye, "Denise Ho: Becoming the Song' Review: Pop With a Message”, July 3, 2020.

7 They are Harisu, a singer and actress in Korea, Jin Xing, a dancer turned talk-show and dating show hostess in China and Dorcee Gamalama, a comedian and talk-show hostess in Indonesia. Two or three cross-dressing or transgender television presenters gained popularity in India and Pakistan, for example Rose Venkatesan in India. Harisu and Jin Xing have had genital surgery, been legally recognized as women, and are married to male husbands. These individuals are not well known outside their home countries.

8 Raymond Chan was elected in Hong Kong. Geraldine Roman, in the Philippines, is from a prominent local political family, giving her high name recognition. There have been 'out' local government elected figures in Japan and some other places.

9 On 21 February 2020, their party, the Future Forward Party, was dissolved by order of the Constitutional Court for breach of party funding rules. Most of the elected members of the party have joined another party, which was rebranded as the Move Forward party. They continue as legislators, except for one disqualified in October 2020, for owning shares in a media company, a prohibition for elected politicians found in Thai law.

10 Reuters, "Election of gay lawmaker spurs hopes for same-sex marriage" Asahi Shimbun, July 24, 2019. Taiga Ishikawa was elected to the Upper House representing the main opposition Constitutional Democratic Party. 
Singapore, Taiwan, Thailand and Vietnam. Over 200,000 people participated in the parade in Taipei in 2019, the biggest such event in Asia. ${ }^{11}$ Singapore's annual Pink Dot event draws thousands but is confined to one park (and foreigners are banned from participating or sponsoring).

'Pride' events in Myanmar were held indoors in hotel premises for a number of years.

"In 2018, authorities granted permission for a Pride event to be held in a public park in Yangon for the first time, and it was attended by some 12,000 people. In 2019, a flotilla of boats sailed down Yangon's river in a Pride boat parade." ${ }^{\prime 2}$

Hanoi Pride events have been held for five or six years in the Goethe Centre in Hanoi, part of the German embassy. The program includes a bicycle rally on public streets - with colorful t-shirts and flags. There are active LGBT non-governmental organizations (NGOs) in both Hanoi and Ho Chi Minh City and chapters of Parents and Friends of Lesbians and Gays (PFLAG). ${ }^{13}$

Hong Kong has seen progress. There are 'pride' parades. There is one out gay elected member of the legislature. The courts have been delivering in LGBTI rights cases for a number of years. The South China Morning Post gives very good coverage to LGBTI stories, whether local, regional or international. Legislative reform is stalled (as it is almost everywhere in Asia).

In Thailand gay/transgender movies regularly gain commercial release and show in local theatres, along with foreign LGBTI offerings. Lesbian characters only very occasionally appear in the Thai films. ${ }^{14}$ The Tourist Authority of Thailand has an advertising campaign expressly aimed at attracting gay and lesbian tourists, a first in Asia. A video from 2013 calls out "Go Thai. Be Free". There is an appealing website. The major Thai cities have quite open gay venues - bars, restaurants, saunas, massage

11 Sarah Zheng, “200,000 join Taiwan's pride march five months after island legalizes same-sex marriage" South China Morning Post, October 26, 2019.

12 Heinrich Boll Stiftung, "Building Space for Lasting Change - LGBTI in Southeast Asia", (30) January 2020), online: Southeast Asia Regional Office <https://th.boell.org/en/2020/01/30/buildingspace-lasting-change-lgbti-southeast-asia>. Apparently, no talk of the repeal of colonial era criminal laws.

13 PFLAG originated in the United States. Independent branches are active in parts of China as well as in Vietnam. See Discussion Paper on Empowerment and Capacity Development for Parents of LGBTI Persons in Asia, by Cody Freeman \& Timo Ojanen (ILGA Asia et al, 2019).

14 The author has lived in Bangkok since 2003 and has seen many of these films, shown in regular commercial theatres. Most do not circulate outside Thailand.

15 See www. gothaibefree.com, showing 8 different same-sex couples enjoying themselves at different sites in the Kingdom. The government's Tourist Authority of Thailand hosted a two-day LGBT+ Travel Symposium at the So Sofitel hotel, a gay friendly venue, in the central business district, June 29-30, 2018, and earlier in the year had been the presenting LGBTI partner at ITB Berlin 2018: Xingi Liang-Pholsena, "Finally, Thailand comes out of closet” Travel Trade Group, July 2, 2018. 
parlors and hotels. ${ }^{16}$ The Covid-19 pandemic has meant the closure of many of these businesses at the time of writing.

Large scale conferences of the International Lesbian, Gay, Bisexual, Transgender and Intersex Association (ILGA) have been held successfully in mainstream hotel or conference facilities in Cambodia, Korea, Philippines, Taiwan - and three times in Thailand. ${ }^{17}$ An Asia regional ILGA conference was blocked in Indonesia in 2010 by Islamist opponents, after delegates had already arrived in Surabaya. ILGA Asia was to meet in Vietnam in 2021, but that is expected to be postponed. Hong Kong is scheduled to host the international Gay Games in 2022.

Large anti-government protests, primarily by young people, occurred in Bangkok in 2020. While Thailand has a history of such protests, none before had included rainbow flags, some assertion of LGBT rights issues and some 'out' leadership. A Reuters headline read "Thai LGBT activists raise pride flag in anti-government rally." A new visibility.

\section{GOVERNMENTAL ATTITUDES}

It has been suggested that there is a policy strategy on the part of authorities in China on LGBTI issues.

"Many argue that the Chinese government's official position on LGBT issues, to the extent that the government has a position at all, follows the so called 'three nots. These are expressed as 'not encouraging, not discouraging and not promoting' homosexuality. This is a cautious political position which the Chinese government has also adopted on a wide range of other social issues which, while controversial, do not challenge China's political settlement." ${ }^{19}$

This policy involves saying as little as possible, while allowing a limited gay scene. The limits of tolerance are left unstated. China actually expressly banned the film portrayal of homosexuality in 2008, but abolished the ruling in 2010 , leaving only an

16 See the website of Gay Travel Asia. There is also a free English language bar guide magazine for tourists, Thai Puan (Thai friend), but it is suspended during the pandemic.

17 ILGA world conferences have been held in Bangkok and Manila. The others in Thailand were for the Asia regional organization.

18 Juarawee Kittisilpa, Thai LGBT activists raise pride flag in anti-government rally, Reuters, July 25, 2020; At Thai protests LGBT activists strengthen calls for gender and marriage equality, South China Morning Post, September 21, 2020; Jiraporn Kuhakan, Reuters, The local protest leader who emerged with a kiss, Bangkok Post Life, September 28, $2020,8$.

19 Tom Mountford, "China: The legal position and status of lesbian, gay, bisexual and transgender people in the People's Republic of China” (2010) website of OutRight Action International, paragraph 15, page 8. The present writer has found no source in which this formulation is actually applied by Chinese authorities to LGBT matters, but activists in China say that it is descriptive of the reality of the situation. 
earlier prohibition of "obscene" content. The message seemed to be that it was better to say nothing explicitly on homosexuality. ${ }^{20}$ Vietnam had a law prohibiting holding an event and calling it a same-sex wedding. The law was repealed, without substituting any legal recognition of same sex relationships. A preference for silence is usually an accurate description of government policies in China, India, Japan, Laos, Myanmar, Philippines, Singapore, and Vietnam. ${ }^{21}$

There is active and vocal opposition to LGBTI visibility and rights by government in Malaysia. Leading political figures regularly condemn homosexuality as something only tolerated in the West and undeniably condemned by Islam - and, they add, by "all religions". The Pakatan Harapan coalition won the 2018 election in Malaysia on a platform that included advancing human rights. That did not include LGBTI rights and there was no implementation of the campaign promises on human rights anyway. ${ }^{23}$ Controversy forced an openly gay press officer, serving the youth and sports minister, to step down in July 2018. ${ }^{24}$ The 2018 annual Georgetown arts festival in Penang state recognized a dozen or so prominent Malaysian figures. The national Minister of Religious Affairs ordered the removal of two photographs of activists. One was gay, the other transgender. ${ }^{25}$ Those images promoted sex/gender diversity. Compounding this

20 John Wei, Queer Chinese Cultures and Mobilities: Kinship, Migration, and Middle Classes (Hong Kong: Hong Kong University Press, 2020).

21 It seems accurate for President Joko Widodo in Indonesia, but not for many others currently holding national political office in the country, who are in vocal opposition to LGBTI rights.

22 In recent years, only Prime Minister Badawi avoided saying anything about homosexuality. In Malaysia that was very positive. He was explicitly very good on women's issues. During Badawi's time as Prime Minister, Anwar Ibrahim was acquitted of the first sodomy charge against him by the final court of appeal and released from jail (see section 9, below). A biography depicts Badawi as a failed reformer: see Kee Beng Ooi, Arrested reform: the undoing of Abdullah Badawi (Kuala Lumpur, Malaysia: Research for Social Advancement, 2010).

23 The coalition lost power in March 2020, to a new coalition, more narrowly Malay and Islamic in character. The Pakatan Harapan had promised accession to the Convention on the Elimination of Racial Discrimination and the International Criminal Court but backed off on both promises in the face of opposition, well before losing power.

24 The Youth and Sports Minister Syed Saddiq Abdul Rahman did not dismiss the media aide Numan Afifi, a gay rights advocate, and publicly thanked him for his work: Shannon Power, "LGBTI activist forced to resign from minister's office because he's gay" GayStarNews, July 11, 2018. And see Beng Hui Tan, "The LGBT Quandary in New Malaysia” (2019) 20:1, article 15 Australian Journal of Asian Law, online: <https://papers.ssrn.com/abstract=3489659>.

25 AFP, "Kuala Lumpur slammed over removal of LGBT portraits" The Nation (Bangkok) August 10, 2018, 5A. The gay activist whose photograph was removed, Pang Khee Teik, was the most visible organizer of Seksualiti Merdeka, whose very visible annual arts and information festival was banned by police order in November 2011. A judge refused judicial review of the legality of the banning. See Beng Hui Tan, Sexuality, Islam and Politics in Malaysia: A Study of the Shifting Strategies of Regulation Department of Southeast Asian Studies, National University of Singapore, 2012) [unpublished]; Douglas Sanders, "Sex and Gender Diversity" (2016) 2 chapter 11 Southeast Asian Human Rights and Peace Studies Network (An Introduction to Human Rights in Southeast Asia) online: 
censorship, the official responsible said he was protecting the two individuals, who might otherwise end up as victims of witch-hunts. The activists, who had been struggling to gain space in the public sphere, were to be kept out of sight - for their own good. ${ }^{26}$

In Singapore, no elected political figures support LGBTI rights or the repeal of the colonial-era criminal prohibition of acts of "gross indecency" between males. Organizations supporting LGBTI rights are barred from official registration, which is legally required for all civil society organizations. Some function anyway.

Indonesia, alone, has seen clear and vocal regression. ${ }^{27}$ While there had been little or no vocal elite support for LGBTI rights in past decades, hostile views were generally unspoken. Since early 2016 politicians, educators, psychiatrists and Islamic figures have called for the criminalization of homosexual acts and compulsory treatment. ${ }^{28}$ The Minister of Higher Education at one point said that LGBTI should be barred from universities. ${ }^{29}$

Indonesia is distinctive in the extent to which activist Islamist groups have taken the initiative into their own hands to block LGBT events, raid parties and force police to turn up and arrest people. The rise of these activist fundamentalist groups, most famously the Islamic Defenders Front, occurred in the disorder after the fall of President Suharto in 1998. In recent years, Islamic vigilantes have raided LGBT events, even events sponsored by the Ministry of Health or the National Human Rights Commission. President Joko Widodo has condemned discrimination but said as little as possible. On LGBTI issues he has not been in control of his cabinet or the legislative branch. His vice-president in his second term is a very well-known senior cleric who has supported criminalization of same-sex acts. ${ }^{30}$

In parts of Asia, LGBTI issues are seen by some authorities and politicians as a legitimate part of state policies on human rights. This describes the situation in Cambodia, Taiwan and Thailand. ${ }^{31}$ The exact motivations for such a commitment vary.

<https://www.academia.edu/43201788/Sex_and_Gender_Diversity_in_Southeast_Asia> at 115116.

26 Tan, supra note 24.

27 Brunei, Malaysia and Singapore have not regressed, simply restated or continued existing policies.

28 In February 2016, the director of mental health at the Ministry of Health called homosexuality a "psychiatric disorder", a view repeated a few days later by the Indonesian Psychiatrists Association: See Human Rights Watch, "Scared in Public and Now No Privacy: Human Rights and Public Health Impacts of Indonesia's Anti-LGBT Moral Panic”, (2018), online: Human Rights Watch <https://www.hrw.org/report/2018/07/01/scared-public-and-now-no-privacy/human-rights-andpublic-health-impacts>.

29 Marguerite Afra Sapia, “Govt officials’ LGBTIQ statements labeled unconstitutional” Jakarta Post, January 28, 2016.

30 See Norshahril Saat, "The Implications of a Ma'ruf Amin Vice-Presidency in Indonesia" (2019) 20198.

31 Since Cambodia and Vietnam have been regularly condemned for human rights abuses in recent decades, their relative or limited support for LGBT rights may, in part at least, be a limited rebuttal to outside criticism. 
Some politicians seek international recognition of good practices. Sometimes support for human rights comes from competition between political parties.

Chen Shui-bian, president of Taiwan from 2000-2008, was the leading figure in Asia, perhaps the world, in publicly asserting his administration's support for human rights and LGBT rights. This was a key part of his campaigns for favorable international recognition for the island. No other self-governing place has faced the same kind of challenge to its legitimacy. It is excluded from the United Nations and other international inter-governmental organizations - and threatened by China for resisting unification. The leaders of the two main political parties in Taiwan, despite being direct competitors, have been vocal in support of LGBTI rights, making the island unique in the Asian region. ${ }^{32}$ Taiwan prohibits discrimination in employment, recognizes some transgender rights and hosts large 'pride' parades each year. Equal rights to legal marriage became the law in Taiwan in 2019, the first in Asia and the $29^{\text {th }}$ jurisdiction with marriage equality internationally.

The sharp differences in attitudes on 'human rights' among member governments of ASEAN made a reference to them in the Charter of the Association of Southeast Asian Nations something of a heroic achievement. Opposition from Brunei, Malaysia, Myanmar and Singapore was only overcome by entrenching the unanimity requirement for any actions. Individual government representatives on the ASEAN Intergovernmental Commission on Human Rights from Indonesia and Thailand have consistently been supportive of LGBTI rights, but the Commission has been silent. There is an active regional NGO, the ASEAN SOGIE Caucus. The Southeast Asian Human Rights and Peace Studies Network (SEAHRN) holds biennial conferences of academics and students. It has published An Introduction to Human Rights in Southeast Asia in two volumes $(2015,2016){ }^{33}$

\section{SOCIETAL ATTITUDES}

Public attitudes vary in the Southeast Asia region. What may be the only fairly reliable study covers six countries: Indonesia, Malaysia, Philippines, Singapore, Thailand and Vietnam. In a large 'values' study, respondents were asked to choose (from a list of various categories) the kinds of people they would not want as neighbors. The percentage that included homosexuals in their list was $66.1 \%$ in Indonesia, $58.7 \%$ in Malaysia, 27.9\% in the Philippines, 31.7\% in Singapore, 39.8\% in Thailand and $29.1 \%$ in Vietnam. Respondents in the study who said that homosexuality was never morally

32 Chen (of the DPP) and Ma (of the KMT) were taking a risk - there could be societal backlash and, rather perversely, their delays in delivery gave time and space for an opposition to develop (in a country where the opposition had a very narrow base).

33 Sanders, supra note 25. 
justified were $87.6 \%$ in Indonesia, $60.5 \%$ in Malaysia and $31.1 \%$ in the Philippines. ${ }^{34}$ Other studies identify the Philippines as the most tolerant country on LGBTI issues in Asia.

\section{RELIGIOUS CONCERNS}

Religion looms high in campaigns against the recognition of LGBTI legitimacy. Independence constitutions in Asia were basically secular in character. State patronage of religion is clear in Brunei, Indonesia, Malaysia and Thailand. Constitutions in Brunei and Malaysia recognize Islam as the official state religion, while allowing other religions to be practiced freely. ${ }^{36}$ While the government of Indonesia is actively involved in religious matters, the state is said to be secular. Former President Susilo Yudhoyono, a mainstream figure, stated this clearly:

"Indonesia is not a Muslim country and any efforts to turn it into one must be resisted. ... Secularity is final, and this is an important legacy that we have inherited from Sukarno and the other founders of the republic." ${ }^{37}$

In contrast Malaysia expanded government Islamic programs in the long competition between $U M N O$ (the United Malay National Organization) and PAS (the Islamic Party of Malaysia). ${ }^{38}$ At one-point Prime Minister Mahathir Mohammed stated that Malaysia was an 'Islamic state'. Political parties are mostly communal in Malaysia, unlike other parts of Southeast Asia.

In some Asian states, organized opposition to LGBTI rights comes from particular religious groupings within the society. There have been highly organized and wellfunded campaigns against reforms by evangelical Christian minorities in Hong Kong, Korea, Singapore and Taiwan.

34 Eric Julian Manalastas et al, "Homonegativity in Southeast Asia: Attitudes towards lesbians and gay men in Indonesia, Malaysia, the Philippines, Singapore, Thailand and Vietnam” (2017) 17:1 AsiaPacific Social Sciences Review 25-33 at 28-29.

35 Andrew R Flores, Social Acceptance of LGBT People in 174 Countries: 1981-2017 (Williams Institute, UCLA School of Law, 2019).

36 Article 3(1) of the Constitution of Malaysia reads: "Islam is the religion of the Federation, but other religions may be practiced in peace and harmony in any part of the Federation.” The list of State level legislative powers, List II in the Ninth Schedule gives legislative power to the states to have Islamic law and Malay custom apply to Muslims in matters of personal law, Islamic charities and in relation to offences to the extent conferred by federal law. In this context the Sharia courts can determine matters of Islamic law and Malay Custom.

37 Ezra Sihte, "Keep Indonesia secular, Yudhoyono urges” Jakarta Globe, May 7, 2014. As president he banned Amadi from any proselytization, and declined to enforce court orders authorizing the construction of new churches, contradicting his views that the government must act in a secular manner.

38 Tan, supra note 25 at 33. 
In October 2020, the story broke that Pope Francis supported civil union laws for same-sex couples, saying they had a right to legal support. He rejected same-sex marriage. Francis had suggested civil unions ten years earlier when Archbishop of Buenos Aires, but that was in an attempt to counter Argentina's decision to open marriage to same-sex couples. Now as Pope, he was repeating that position. ${ }^{39}$ Support for LGBTI was already strong among some Protestant denominations. Southeast Asia seems to have no active opposition from Buddhist figures.

\section{CRIMINAL LAWS}

Criminal laws against same-sex acts have been held to violate the provisions on privacy and equality in the European Convention on Human Rights and the International Covenant on Civil and Political Rights (ICCPR). ${ }^{40}$ In ASEAN, only Brunei, Malaysia, Myanmar and Singapore are not 'state parties' to the ICCPR. Other states in Southeast Asia, including Timor Leste, are bound, in terms of international law, to the provisions in the Covenant.

In Asia, criminal laws prohibiting same-sex acts between men were put in place by British colonial governments and, in the case of Central Asia, by the government of the Soviet Union. Most of these laws remain in effect. Other colonial powers in Asia France, Netherlands, Portugal, Spain and the United States - left no equivalent laws. ${ }^{42}$ In Southeast Asia, national criminal codes have British formulated prohibitions in Brunei, Malaysia, Myanmar and Singapore. Criminal prohibitions were ended in Hong Kong and Bhutan by legislative repeal and in India by a rights-based constitutional

39 Harlan, Bootrstein, Bailey, Pope Francis calls for civil union laws for same-sex couples, Washington Post, October 22, 2020.

40 The decision of the Human Rights Committee in the case of Toonen v Australia in 1994 held that the International Covenant on Civil and Political Rights prohibited discrimination on grounds of sexual orientation. The decision found the criminal law in the state of Tasmania to be in violation of the ICCPR. The European Court of Human Rights has ruled against such laws, beginning with the 1981 decision in Dudgeon $v$ UK. The leading European decisions dealt with criminal laws in Northern Ireland, Ireland and Cypress.

41 Justice See in the Singapore High Court in March 2020, ruled that one of the reasons for declining to follow decisions in other jurisdictions, striking down similar criminal laws against same-sex acts, was that some of the countries involved were parties to particular human rights treaties, while Singapore was not. See Gay Sex Still a Crime in Singapore Thanks to Dubious Legal Rulings, by Philippe LeDoux (Human Rights Watch, 2020).

42 The US colonial period in the Philippines did not displace the Spanish criminal law already in place. The Japanese colonial period in Korea and Taiwan did not have prohibitions in criminal laws. Two prosecutions of military have recently been reported in Indonesia under provisions that are not specific on homosexuality: Asia News Network, Amnesty International condemns Indonesia military for 'anti-LGBT campaign', Phnom Penh Times, October 18, 2020. 
ruling in $2018 .^{43}$ China, Japan, Korea, Taiwan and Thailand, with their separate histories, have no criminal law prohibitions. ${ }^{44}$

Decentralization of legislative, administrative and financial powers to local governments was a striking innovation of the Habibie government in Indonesia, shortly after the 1998 fall of President Suharto. The reform led to local governments enacting what were seen as Sharia inspired, local laws on alcohol, proper dress, religious observance and sexual conduct. ${ }^{45}$ There seems little attention or controversy about these local laws at present. They are not true criminal law but can have the same effect. Current information on enforcement is lacking.

The present national penal code in Indonesia was inherited from the Dutch colonial period. The legislature has been attempting a revision of the code since 1964 . Recurring media stories have suggested that new provisions will ban homosexual acts. ${ }^{46}$ The then UN High Commissioner for Human Rights, Zeid Ra'ad Al Hussein of Jordan, travelled to Indonesia to make a public plea to President Joko Widodo to block criminalization. ${ }^{47}$ Later, in 2019 , media reports indicated that amendments to the penal code would block all sexual acts outside of marriage. President Joko Widodo, facing re-election, convinced the legislative branch to put any action off until the next session (after the election). Enactment then failed. As noted, Jokowi's second term vice president is a cleric who has backed criminalization. ${ }^{48}$ An attempt to attain criminalization through constitutional litigation was rejected five to four by the Constitutional Court in 2017. ${ }^{49}$ In February 2020, the House of Representatives began

43 In 2007 Singapore repealed the colonial era prohibition of "carnal intercourse against the order of nature” because it could apply to heterosexual anal intercourse but retained a separate British prohibition of acts of "gross indecency" between males.

44 See Douglas Sanders, "What's Law Got to Do with It? Sex and Gender Diversity in East Asia" in Mark McLelland \& Vera Mackie, eds, Routledge Handbook of Sexuality Studies in East Asia (Routledge, 2014) 127. South Korea prohibits homosexual acts by military personnel. In the Middle East, most states inherited secular criminal codes from the Ottoman Empire. Those laws were based on the French Napoleonic penal code, with no prohibition of same-sex acts.

45 Michael Buehler, The Politics of Shari'a Law: Islamist Activists and the State in Democratizing Indonesia. (Cambridge University Press, 2016).

46 Human Rights Watch, supra note 28 at 38; Saskia E Wieringa, "Criminalisation of Homosexuality in Indonesia: The Role of the Constitution and Civil Society” (2019) 20:1, article 17 Australian Journal of Asian Law, online: <https://papers.ssrn.com/abstract=3488561> at 5.

47 Human Rights Watch, supra note 28 at 41.

48 Ma'ruf Amin had been an advisor to former president Susilo Bambang Yudhoyono, and in that period backed restrictions on Ahmadiyah and the construction of Christian churches. $\mathrm{He}$ supported criminalization of homosexual acts and urged the prosecution of Basuki Tjahaja Purnama, former governor of Jakarta, for blasphemy. See Ben Otto, Wall Street Journal, Fatwas, blasphemy claims put cleric on path to power, January 25, 2019; Saat, supra note 30.

49 An English language translation of the judgments forms an appendix in the 2018 Human Rights Watch publication. 
consideration of a so-called Family Resilience Bill, which, among other things, would require LGBT people to register and undergo compulsory treatment. ${ }^{50}$

Since 2007, Singapore has had an express policy of not proactively enforcing its colonial era 'gross indecency' law but leaving it in force. The government tolerates gay and lesbian bars and gay saunas. There is a campaign by activists for decriminalization. The campaign has received no support from any politicians in the governing or opposition parties. One or two respected senior retired politicians have supported repeal. A second attempt at decriminalization by constitutional litigation was rejected at the trial level in April 2020 and is under appeal. ${ }^{51}$

In September 2018, the Indian Supreme Court ruled that the colonial era criminal prohibition of 'carnal intercourse against the order of nature' breached constitutional human rights provisions. The decision was important for ASEAN, for the Indian Penal Code provisions of 1860 had been copied in the laws of Brunei, Malaysia, Myanmar and Singapore. The national government in India had remained silent on the issue during the long period of litigation and even in the face of the final decision. The government allowed competing submissions to the courts by the justice ministry and the national AIDS control agency (one supporting the criminal law, the other opposing). In contrast, the opposition Congress Party took a position, coming out very late in support of decriminalization. ${ }^{52}$

In $A S E A N$, anti-LGBT criminal law takes different forms in different parts of the region. Only in Indonesia and Malaysia is the actual enforcement of some form of criminal law against same-sex sexual activity a recurring, but occasional, feature of life. These days there are no reports of raids on bars, clubs, private parties, contacts in public parks or transgender beauty pageants in other parts of the region.

In all ten ASEAN countries some public venues exist for gay men, whether bars or saunas, perhaps quite limited (with Brunei the exception). Singapore has gay and lesbian bars and regularly scheduled lesbian parties. Manila has gay bars and regularly publicized lesbian parties. ${ }^{53}$ Gay and lesbian dating apps are widely in use and, over twenty years, they have significantly changed LGBT socialization patterns. There has

50 Joshua Mcdonald, LGBT community targeted by police in Indonesia, The Diplomat, September $18,2020$.

51 LeDoux, supra note 41 at 2.

52 See AFP, "Modi govt silent as Indian media hails court ruling to decriminalize gay sex" Straits Times (Singapore), September 8, 2018. A New York Times story commented: "Prime Minister Narendra Modi has said very little about gay rights, despite the conservativeness of his governing Bharatiya Janata Party on some social issues. During the hearings in July, the central government announced that it was not going to take a position on section 377". See Jeffrey Gettleman, Kai Schultz, Suhasini Raj, "India Strikes Down Colonial-Era Ban on Gay Sex" New York Times, September 6, 3018.

53 Information from personal communications. Activists say there are lesbian bars in Japan and China. None exist at present in Thailand. 
been a decline in public LGBT venues in Thailand and the Philippines, and a sharp reduction in the (always limited) LGBT-specific print media.

\section{SHARIA (SYARIAH)}

In areas with Muslim populations or communities, Sharia personal laws dealing with family matters, including inheritance, are often administered by Sharia courts for Muslims. A common pattern was for a jurisdiction to have a secular national criminal code (following either a British or a French model), paired with 'personal' laws administered by religious authorities for Muslims (and perhaps parallel family law systems for other religious communities as well, as existed in the Ottoman Empire). Whether there was a prohibition of same-sex acts was a matter for the secular national criminal codes, not Sharia law. ${ }^{54}$ But at present, in Southeast Asia, Sharia law, while coexisting with a secular national criminal law, has some criminal law jurisdiction in Brunei, Malaysia and Aceh province in Indonesia. Sharia courts in most parts of Indonesia, and in southern Thailand, Mindanao (Philippines) and Singapore have no criminal law competence. ${ }^{55}$

Internationally there was a turn to Sharia law and Islamic governance in the post World War II, post-colonial period. The most dramatic event was the Iranian Revolution of 1979, ending a period of secular westernization in favor of a new system of theocratic control. The most significant innovation in South and Southeast Asia occurred in Pakistan under Zia-ul-Haq, who headed a military government from 1977 to 1988 . He praised the Iranian revolution and accelerated a process of Islamization in Pakistan. ${ }^{56}$ He strengthened the separate Sharia courts. New criminal offences were created for adultery, fornication and blasphemy. The death penalty became possible for homosexual acts.

54 The French criminal law model, widely copied in Europe, including the Netherlands, had no prohibition of homosexual acts. The British model, copied in half the world through colonial expansion, had a prohibition usually using the language of the Indian Penal Code of 1860. The prohibition of 'carnal intercourse against the order of nature' from the Indian Penal Code was a reworking of the British 'buggery' law, which was religious in origin. While there are religious origins, the British model code, like the French equivalent, is seen as a secular law.

55 Tomas Larsson, "Secularisation, Secularism and the Thai State" in Pavin Chachavalpongpun, ed, Routledge Handbook of Contemporary Thailand (Routledge \& CRC Press, 2020) 278 at 278-281; Asian Institute of Journalism and Communication, "Courts for Muslims: A Primer on the Philippine Shari'a Courts" 12; Kerstin Steiner, "Governing Islam: The State, the Administration of Muslim Law Act (AMLA) and Islam in Singapore” (2015) 16:1 Australian Journal of Asian Law 116.

56 Alex Vatanka, Iran and Pakistan: Security, Diplomacy and American Influence, reprint edition ed (London; New York: I.B. Tauris, 2015) at 148 and 155. 
Malaysia was directly affected by the Iranian developments.

"The [foreign educated] ulama [believers] who took over PAS [the Islamic Party of Malaysia] in 1982 drew from the 1979 Iranian revolution for inspiration in establishing an Islamic state. Yusof Rawa ... openly rejected the Malay nationalism that characterized both UMNO [United Malay National Organization] and PAS under [former PAS head] Asri Muda, considering it a narrow and ignorant ideology that was contrary to the concept of a Muslim ummah. As if to exemplify the shift in the party's ideological outlook under Yusof and his ulama colleagues, the party's new leaders adopted a more conservative and religious form of dress, abandoning Malay and western clothing for traditional Arab religious garb. Politics between UMNO and PAS became increasingly religious in nature." ${ }^{57}$

This was a challenge to the 'multicultural' strategy of the Barisan Nasional, the coalition of Malay, Chinese and Indian parties that had governed Malaysia since independence.

The post-war period saw a gradual expansion of Sharia laws in Malaysia. The Malaysian constitution gave the individual states the responsibility for Sharia provisions for Muslims, basically family law matters. The 13 states, and the three federal territories, each have their own Sharia laws and Sharia court systems. There is national jurisdiction over criminal law and a uniform penal code, a standard British colonial pattern. But the state-level Sharia provisions included criminal offences. ${ }^{58}$ Strict limits for any punishments were specified by federal law. ${ }^{59}$ Caning, for example, is limited to six strokes, and there are limits on fines and the length of imprisonment. PAS sought a radical expansion of Sharia criminal law in the hands of the individual states.

"PAS' record on Islamic governance is telling it introduced the Syariah Criminal Code Bill II in Kelantan in 1993; the Syariah Criminal Offences (Hudud and Qisas) in Terengganu in 2002; and in 2003 published the Islamic State Document reiterating the party's vision of an Islamic state, which incorporates the implementation of hudud laws

57 Wikpedia, "Malaysian Islamic Party" section "Ulama takeover (1982-1989)", accessed December 1, 2019. The Barisan Nasional national government, a coalition of Malay, Chinese and Indian parties, tried to counter the possible electoral appeal of PAS by creating a number of state-run Islamic institutions, such as the International Islamic University of Malaysia and financing Mosque construction.

58 Maznah Mohamad, "Politicization of Islam in Indonesia and Malaysia: Women's Rights and InterReligious Relations" in Theresa Devasahayam, ed, Gender Trends in Southeast Asia (Singapore: ISEAS-Yusof Ishak Institute, 2009) at 98-99.

59 State level Sharia law includes "creation and punishment of offences by persons professing the religion of Islam against precepts of that religion.” See Constitution of Malaysia, Ninth Schedule, List II-State List, section 1 and Article 74(2). The extent of punishments (caning, fines, imprisonment) is limited by federal law. 
(punitive Islamic laws). Hudud punishments includes amputation, caning, and stoning to death."

The 1993 Kelantan law faced opposition from then Prime Minister Mahathir and also from the Sultan of Kelantan, Ismail Petra. When PAS governed in the neighboring state of Terangganu, it passed a parallel law in 2002. These laws could not come into force for they exceeded the punishments allowed by federal law for state-level Sharia offences. In recent years, Kelantan has sought a more modest expansion of criminal punishments (100 strokes of the cane, up from six, 30 years imprisonment, up from 3, 100,000 RM fine, up from 5,000).$^{61}$ These increases in penalties have not been allowed.

In Malaysia "cases of consensual homosexual relations being tried in a civil or Syariah court are practically non-existent.... ${ }^{{ }^{2} 2}$ A senior official in the Syariah Judiciary Department in the state of Kelantan said he had never heard of a single case of liwat in his long service. ${ }^{63}$ There have been many Sharia law convictions for males dressing as women, something not covered in national criminal law. Punishments include caning, up to six strokes. An apparently unprecedented raid of a private party in Selangor state by Syariah police in 2018 led to eleven prosecutions. Some pleaded guilty. One challenged the legality of individual state level Syariah laws against homosexual sexual acts, because the matter was covered by national criminal law. That constitutional challenge (on grounds of division of powers in a federal state, not on human rights grounds) may be proceeding. ${ }^{64}$

In Indonesia, a reference to Sharia law as an obligation for Muslims, was considered in the drafting of the independence constitution, and rejected. The reference was considered again in the post-Suharto reform period, and again rejected by the legislature. In 1946 the government set up a Ministry of Religious Affairs to oversee the Islamic courts, which handle matters of family law for Muslims. ${ }^{65}$ A single uniform marriage law was enacted nationally in $1974 .^{66}$ The Sharia courts have no criminal law jurisdiction. In March 2015, the Indonesian Ulema Council issued a fatwa (an Islamic religious ruling) calling for "a host of punishments" for homosexual acts, ranging from caning to the death penalty. While the Council is a government created body, the fatwa is not law.

60 Norshahril Saat, "Will PAS Governments in Kelantan and Terengganu Push for Islamic Laws?" (2018) 2018 ISEAS (Perspective) 2.

61 Norshahril Saat, "The UMNO-PAS Unity Charter and its Impact" (2019) 2019 ISEAS (Perspective) 4.

62 Tan, supra note 25 at 158.

63 Ibid at 130. A chart on 146 shows cases from 2005-2009 in peninsular Malaysia. No cases of liwat are listed, but many for khaliwat (close, unsupervised proximity of unmarried heterosexuals), sex outside of marriage, indecent behavior and gambling.

64 Beth Lih Yi, "Malaysian wins landmark right to challenge Muslim gay sex ban" Thompson Reuters Foundation, May 27, 2020. The raid is described in the later section Other Prosecutions and Police Actions, item 14.

65 Mohamad, supra note 58 at 97.

66 Ibid at 99-100. 
The Indonesian province of Aceh in Sumatra, uniquely in Indonesia, gained legislative authority to enact Sharia criminal law. ${ }^{67}$ On September 14, 2009, the Aceh legislative council enacted provisions allowing stoning to death for adultery and 100 lashes for homosexual acts. The provisions were enacted by an outgoing legislative council. They did not have the support of the incoming council and the provincial governor refused to sign the law. The new penalties never came into force. ${ }^{68}$

In 2014 new laws came into force in Aceh against homosexual acts, whether by men or women, and against adultery. The penalty was up to 100 lashes, or a fine or imprisonment. These provisions apply to Muslims and non-Muslims. Aceh is the only jurisdiction in Southeast Asia which applies Sharia law to non-Muslims. ${ }^{69}$ There have been numerous convictions, including for homosexual acts, and the public caning of both men and women. Caning has become a routine part of Sharia criminal law enforcement in Aceh (with no parallels in other parts of Indonesia). There has been controversy about the caning of women, which is to be performed by women now trained to administer the punishment.

"In April 2016, Aceh's governor Irwandi Yusuf attempted to remove caning from the public eye. However, powerful religious groups such as the Islamic Defender's Front (FPI) opposed these changes, arguing that the public's witnessing of canings was the most effective tool in coercing compliance. Public canings have continued, such is the power and influence of religious groups like FPI." ${ }^{70}$

Brunei is a special case, a tiny, rich Malay Muslim sultanate. Advocacy in Malaysia for full Sharia criminal law influenced developments in Brunei.

"Nik Aziz [former head of government in Kelantan] is like the Pope to the Sultan of Brunei," said a Malaysian businessman with links to the inner circle of the Brunei royal family. A Muslim intellectual with ties to Brunei echoed his words. "It is true, the Sultan has long looked up to Nik Aziz." "11

A new Sharia criminal code was introduced by the Sultan in Brunei, coming into force in stages. The third stage was to include 'hudud' punishments, including stoning

67 This was allowed under an autonomy agreement ending a long separatist insurgency.

68 Nurdin Hasan, "To stone or not to stone: It's a matter of interpretation", (2009), online: Asia Pasific Solidarity Network <https:/www.asia-pacific-solidarity.net/news/2009-11-23/stone-or-notstone-its-matter-of-interpretation.html> Jakarta Globe.

69 Nurdin Hasan, “Aceh Lawmaker: Activists shouldn’t make fuss about shariah for non-Muslims”, (2014), online: Asia Pasific Solidarity Network <https://www.asia-pacific-solidarity.net/index.php/ news/2014-09-24/aceh-lawmaker-activists-shouldnt-make-fuss-about-shariah-non-muslims.html>; “Aceh enacts harsh laws against gays" Bangkok Post, September 28, 2014. Jakarta Globe.

70 Joni Lariat, "Witnessing shame and punishment" Inside Indonesia, October 31, 2019.

71 "High-living sultan becomes a holy terror" Sunday Morning Post (South China Morning Post), May 4, 2014, 13. 
to death for adultery and homosexual acts. On the initial announcement, the United Nations condemned the new code and celebrities in the West called for a boycott of the Beverly Hills Hotel and other enterprises owned by Brunei. Members of the LGBT Equality Caucus of the US Congress urged President Obama to drop both Brunei and Malaysia from the negotiations for the Transpacific Partnership trade initiative, on the basis of their anti-homosexual criminal laws. The International Commission of Jurists protested in an open letter to the Sultan and intervened with a brief when the Committee on the Elimination of Discrimination against Women conducted its periodic review of Brunei's compliance with the women's rights treaty.

In April 2019, for the first time, the third stage offences actually came into force in Brunei, again prompting international controversy and calls to boycott Brunei businesses. $^{72}$ The Sultan announced that the death penalty under the Sharia Criminal Law would not be enforced. ${ }^{73}$ In fact, there was already a moratorium on the death penalty in Brunei, but the new law had called it into question.

In summary, in Southeast Asia, Sharia criminal laws prohibiting sexual acts outside of legal marriage, as well as cross-dressing, are in place in Brunei, Aceh province in Indonesia, and at the individual state level within Malaysia. Caning, incarceration and fines can be imposed as punishments.

\section{THE PROSECUTIONS OF ANWAR IBRAHIM}

The prosecutions of Anwar Ibrahim in Malaysia got international attention because of (a) Anwar's political prominence, (b) the fact that the prosecutions seemed blatantly political - intended to discredit a political rival, (c) the use of a British colonial-era criminal law that was used in almost no other prosecutions in Malaysia and (d) the use of a law discredited in international human rights law and repealed in Eastern and Western Europe, the Americas and Australasia. ${ }^{74}$

In 1998, Anwar Ibrahim was both Finance Minister and Deputy Prime Minister in Malaysia. He first rose to public attention as a co-founder of the Muslim Youth Association of Malaysia. He was clearly a Malay Muslim figure, and his wife and daughters wear Muslim headscarves. Getting Anwar to join $U M N O$, rather than align with $P A S$, was "Mahathir's biggest coup" in the long competition to gain the Malay Muslim vote. ${ }^{75}$ Anwar became the political 'heir apparent' to Prime Minister Mahathir

72 Anya Crittenton,"Brunei defends new anti-LGBTI law: 'Stoning gay people will be rare" GayStarNews, April 19, 2019.

73 Joe Brock, "Brunei says it won’t enforce gay death penalty after backlash" Reuters, May 5, 2019; AFP, "Brunei backs down on LGBT penalty" Bangkok Post, May 7, 2019, 6; Rafaella Gunz, "Brunei announces it will not enforce death penalty for gay sex, following global condemnation" GayStarNews, May 5, 2019.

74 The best account of the two prosecutions is Mark Trowell, The Prosecution of Anwar Ibrahim: The Final Play (Marshall Cavendish International (Asia) Private Limited, 2015).

75 Tan, supra note 25 at 34 . 
Mohammad and a very popular figure. He fell out with Mahathir over the government's policy response to the 1998 Asian financial crisis. He was abruptly dismissed. After mounting campaign rallies against the government, he was charged and convicted under Malaysia's colonial era criminal law against homosexual acts. He served five years in prison. ${ }^{76} \mathrm{He}$ was charged and convicted again in $2015 .{ }^{77}$ In both cases, the alleged partner filed a complaint, saying that, as an aide or employee, he was under compulsion to acquiesce in the act. It was not police enforcement actions that led to either charge. Anwar maintained his innocence in both cases, saying the charges were politically fabricated, aimed at ending his political career. He publicly opposed recognition of LGBTI rights. ${ }^{78}$

With the surprise defeat of Prime Minister Najib's coalition government in Malaysia in the May 2018, election, a new coalition government, Pakatan Harapan, took office with Anwar as the de facto leader. ${ }^{79} \mathrm{He}$ was still in prison. On a temporary basis, Mahathir Mohammad, now 92, served as prime minister. Controversially, the coalition included the largely Chinese Democratic Action Party, and, for the first time, a non-Muslim, an Indo-Malaysian, Tommy Thomas, became Attorney General. King Sultan Muhammad V sought to block that appointment but backed down when Mahathir's government refused to change the candidate. ${ }^{80}$ Six members of the $D A P$ gained cabinet positions, including Lim Guan Eng as Minister of Finance. It was a multicultural cabinet. Anwar was granted a royal pardon, released from jail and won a parliamentary seat in a by-election. Mahathir promised to step down in favor of Anwar, but only after a transition period. Anwar was again the 'heir apparent' to Mahathir. The new coalition had promised to ratify the $U \boldsymbol{N}$ convention against racial and ethnic discrimination, but opposition parties organized protests, saying that would threaten Malay preferential rights. ${ }^{81}$ Ratification was put off. Accession to the treaty establishing the International Criminal Court was also promised and put off in the face of protests by the Sultans, the constitutional protectors of Islam, whose powers had been cut back by Mahathir when he was Prime Minister, years earlier.

76 He was convicted both for the alleged sexual activity and for suppressing the investigation while still part of the government, a corruption charge. The final appeal, to the Federal Court, reversed the sodomy conviction on technical grounds and Anwar was released. The concurrent sentence for the corruption charge had already been completed.

77 He was acquitted at trial, on the basis that the forensic DNA evidence was unreliable but convicted on appeal.

78 Rahimy Rahim, "M'sia must not bow to international pressure on LGBT issues, says Anwar" Star Online, May 15, 2019.

79 The coalition brought together parties (a) representing Malay Muslims headed by Mahathir Mohammad, (b) a party with diverse members, headed by Anwar Ibrahim, and (c) a party representing Chinese Malaysians.

80 AP, "A look at Malaysia's monarchy" (February 23, 2019). Malaysia is a constitutional monarchy, and the King Sultan gives royal assent to federal appointments and legislation.

81 Tens of thousands joined a street demonstration to protest ratification: Clive Kessler, "Malaysia's inchoate alliance” Nikkei Asian Review, January 14, 2019, 52. 
There were echoes of the Anwar prosecutions in subsequent allegations of homosexual acts. One was against Azmin Ali, the Economic Affairs minister in the coalition government, a person seen as a possible successor to Mahathir (if the promise made to Anwar was not honored). A video clip of an all-male sex party circulated with a figure said to be him. ${ }^{82}$ Were elements in the Anwar camp trying to eliminate a possible rival? Anwar sharply rejected that allegation. There was also another allegation of homosexual acts leveled against Anwar, which authorities refused to prosecute after an investigation. ${ }^{83}$

Defections meant that the Pakatan Harapan coalition lost its parliamentary majority in March 2020. A new prime minister headed a coalition based on Malay nationalism that included the United Malay National Organization and its coalition partners, the grouping that had lost power in the 2018 election. Perhaps these shifts were designed to block Anwar from becoming Prime Minister (and block the Chinese $D A P$ from continuing to share power). ${ }^{84}$ Azmin Ali, who apparently had been falsely accused of homosexual acts, became minister of International Trade and Industry in the new coalition government. ${ }^{85}$

Nowhere else in Asia has there been any parallel to the series of politically charged allegations of homosexual activity against one - then two - prominent politicians. How do you discredit a rival in Malaysia? Make accusations of homosexuality.

\section{OTHER PROSECUTIONS AND POLICE ACTIONS}

What are the criminal laws against LGBT that can be invoked in some ASEAN countries?

1. Prohibitions of sexual acts found in colonial era national penal codes in Brunei, Malaysia, Myanmar and Singapore. These laws deal with men. In Malaysia alone the penal provisions were extended to same-sex acts by women.

2. There are also petty criminal law offences, such as vagrancy or disorderly conduct, for which convictions are usually easily secured for gay men or transgender individuals gathering in public, particularly at night.

82 Straits Times, Asia News Network, "Man behind M'sia sex clip told to explain himself” The Nation (Bangkok), (June 21. 2019) 5A.

83 Reuters, "Malaysia says no case against PM-in-waiting Anwar over sex assault allegations" (January 14, 2020).

84 The new coalition was very Malay Muslim. See Ahmad Fauzi Abdul Hamid, "The return of oldstyle Malay-centric politics?” (2020) East Asia Forum (Canberra), online: <https://www.academ ia.edu/42848717/The_return_of_old_style_Malay_centric_politics_East_Asia_Forum_Canberra_2 5_April_2020_URL_https_www_eastasiaforum_org_2020_04_25_the_return_of_old_style_malay_ centric_politics_>.

85 Francis Hutchinson, "Malaysia’s surprise new cabinet” East Asia Forum, (April 17, 2020). 
3. Sharia criminal law offences aimed at sexual activity outside of marriage (found in the law in Aceh province of Indonesia, Brunei and in the individual states in Malaysia).

4. Sharia criminal law offences aimed at cross dressing (in the individual states in Malaysia and one case in Brunei).

5. The Anti-Pornography law in Indonesia, which has been applied to depictions and gatherings.

It should be noted that anti-LGBTI religious vigilantism, sometimes on its own, sometimes pushing police to act, is unique to Indonesia. It has been a recurring part of post-New Order Indonesian life. The pornography law seems to encourage vigilantism. One section reads:

"Society has a collective role in preventing the production, dissemination and the use of pornography. ${ }^{86}$

Since most sexual activity takes place in private, anti-homosexual laws require active policing if they are to have more than symbolic or occasional impact. No police force in south, southeast or east Asia attempts effective enforcement. In India less than 200 individuals had been prosecuted under Article 377 in the 150 years preceding the litigation challenging the section (and many of those cases would have involved underage partners or coercion, not consenting adults). ${ }^{87}$ The Supreme Court in Sri Lanka has stated that there should not be laws against private consenting adult sexual acts, while suspending a sentence in $2016 .^{88}$

A leading politician in a Pacific island state justified retaining a prohibition as "a deterrent to people to come out in the open and be open about it." ${ }^{\not 99}$ The message was that the purpose of the criminal law was to ensure that gays and lesbians stayed in the closet'. The success of such a 'containment' strategy is perhaps confirmed by the Malaysian Tourism Minister, Mohamaddin Ketapi. When questioned on policy while in Germany, he said he was unaware that any gay people lived in Malaysia. ${ }^{90}$

86 Translation in Mohamad, supra note 58 at 100.

87 The figure is given in the Supreme Court decision that rejected the challenge to 377 . The Supreme Court later revisited the case and struck down the section on constitutional rights grounds. See Arvind Narrain, "Vacillating between empathy and contempt: the Indian judiciary and LGBT rights" in Nancy Nicol et al, eds, Envisioning Global LGBT Human Rights: (Neo) colonialism, Neoliberalism, Reistance and Hope (London: SAS Publications, 2018) at 54.

88 The constitution of Sri Lanka does not give courts the power of judicial review of the validity of legislation, so the decision in Wimalasiri vs Police, November 30. 2016, could only suspend a sentence, while calling for repeal.

89 Rashneel Kumar, "Under pressure from churches, Cook Islands MPs back down on same-sex law reform” Cook Island News, November 3, 2019.

90 Tashny Sukumaran, "Where does Malaysia stand on gay rights?" South China Morning Post, March 11, 2019; “'No homosexuals in Malaysia' - Malaysian Tourism, Arts and Culture minister says”, Thaiger, March 6, 2019. 
Prosecutions can take place even when the main criminal law is silent. The charge in Egypt is 'debauchery'. The charge of 'hooliganism' was used in the past in China against gay males cruising in parks. Charges in Indonesia are for violation of the 2008 anti-pornography law, not the penal code. Actual prosecutions seem extremely rare.

In recent years there have been some accounts of police actions and prosecutions in Indonesia, Malaysia and Thailand, leaving aside the two exceptional cases against Anwar Ibrahim. Media accounts, available to the present author, have not described prosecutions in other ASEAN countries. Information on cases comes from various sources, mainly established wire services like Reuters and AFP, and from reports by the leading international non-governmental organization Human Rights Watch.

It is unusual to group such enforcement information on a regional (not a national) basis. A regional grouping shows that police actions and actual prosecutions are not dictated by the specifics of legal prohibitions. While it is accurate to say that national criminal law in Indonesia has no prohibition of same-sex sexual activity, the reality is that the situation is much worse for LGBTI in Indonesia than in Singapore, where such a prohibition exists. Routine police practices in Thailand allow commercial homosexual and heterosexual venues to function (with regular unofficial payments). That has more of a positive impact on LGBTI lives than the lack of any criminal law prohibition of sex acts. In spite of the inadequacy of available reporting, and the different laws and politics in the region, some general points will be made at the end of the section.

1. 2016, October, Sulawesi Facebook posting.

Two males in North Sulawesi, Indonesia, were charged under the pornography law and the electronic information law for posting a set of pictures on Facebook showing them shirtless and kissing, while lying on a couch or bed. The message read "With my dear lover tonight. May our love last forever."

2. 2016, November, Pancoran raid in Jakarta.

Late Saturday evening, November 26, 2016, members of the Islamic Defenders Front (FPI) raided a private all male party in a condominium unit in the Pancoran area of Jakarta. Fifty FPI members entered the apartment shouting 'Allahu Akbar.' The men in the apartment were shirtless. No sex acts were witnessed. Police arrived shortly thereafter, and 13 men were detained, as demanded by the FPI. Police confiscated smart phones, condoms and antiretroviral drugs used to control HIV. There are no reports of actual charges being laid. ${ }^{92}$

91 Michael Fitzgerald, "Indonesian police arrest two gay men for affectionate facebook photos" Towleroad, October 14, 2016; Shehab Khan, "Gay couple arrested after uploading a picture to facebook in Indonesia” The Independent October 14, 2016; Hendri Yullus, "Double Standards: The defining of homosexuality as pornographic in Indonesia” Jakarta Post, October 21, 2016.

92 Evi Mariani, "FPI barges into an apartment, forcing police to arrest several men” Jakarta Post, November 27, 2016; Indra Budiari, “After FPI tipoff, police raid alleged gay sex party, arrest 13” 
3. 2017, January, South Sulawesi.

Police in South Sulawesi province cancelled a public sports and cultural event involving transgender people after the Islamic Congregation Forum, a militant Islamist organization, complained the event violated "religious values." Police temporarily detained 600 transgender and Bissu just hours before the three-day event were scheduled to begin. ${ }^{93}$

4. 2017, March, forcible entry in Aceh.

In March suspicious neighbors forcibly entered an apartment in Aceh where two males were engaged in sexual activity. A hand phone video recorded their distress. Two months later they were publicly flogged under Aceh's Sharia criminal law. ${ }^{94}$

5. 2017, April, hotel room party in Surabaya.

On April $30^{\text {th }}$, 2017, police raided two hotel rooms in Surabaya were a group of men were having a party. Police said some of the men were watching gay pornography and others were involved in 'deviant sexual acts.' Fourteen were detained and tested for HIV. Eight were charged under the Anti-Pornography law. The police said they were responding to tip-offs from neighbors. ${ }^{95}$

6. 2017, May, West Java.

The West Java province chief of police, Anton Charliyan, announced a plan to establish a taskforce to actively investigate LGBT activity. Speaking in Bandung, he said LGBT people suffered from a "disease of the body and soul."

7. 2017, May, Aceh.

In May 2017, two men were convicted of homosexual acts under the Sharia criminal law in the province of Aceh. The punishment was a public caning with 85 lashes. The punishment took place in $2018 .^{97}$

8. 2017, May, Atlantis gym, Jakarta.

In May 2017, police arrested 141 men at a gay gym and sauna in North Jakarta. Police released photos of some of the men in varying states of undress, revealing

Jakarta Post, November 28, 2016.; "Indonesia's political Islam and liberalism - Opinion” Jakarta Post, April 4, 2017.

93 Kyle Knight, "Indonesian Police, Anti-LGBT Islamists Restart Sinister Collaboration" Human Rights Watch, January 23, 2017.

94 Andreas Harsono, "Indonesian police raid 'gay party", Human rights Watch, October 7, 2017.

95 Shannon Power,"Police detain 14 men for holding 'gay party' in Indonesia” GayStarNews, May 1, 2017; AFP, "Eight men face jail over 'gay party' in Indonesia as homophobia grows" The Nation (Bangkok), May 2, 2017, 5A; Indonesia: “Gay porn' arrests threaten privacy” Human Rights Watch, May 4, 2017.

96 Tom Allard, Stefanno Reinard, "New police task force targets Indonesian gays" Bangkok Post, Spectrum, May 28, 2017, 10.

97 Editorial: "In step with the Nazis?" Jakarta Post, May 24, 2017. 
personal identities. ${ }^{98}$ Ten people were charged under the Anti-Pornography law. The national human rights commission called the raid and the handling of the arrests 'inhumane'. ${ }^{99}$

9. 2017, October, police raid on T1 sauna in Jakarta.

On October $6^{\text {th }}, 2017$, police raided a Jakarta sauna popular with gay men, detaining 51 people, including eight foreigners. Five employees were charged under the Anti-Pornography law. ${ }^{100}$ The sauna was closed..$^{101}$

10. Human Rights Watch overview.

Throughout 2017, Indonesian police raided saunas, night clubs, hotel rooms, hair salons, and private homes on suspicion that LGBT people were inside. In total, Police apprehended at least 300 people in 2017 alone because of their presumed sexual orientation and gender identity - a spike from previous years and the highest such number ever recorded in Indonesia. ${ }^{102}$

11. 2018, January, beauty salons in Aceh.

Regular police and Sharia police jointly raided five hair salons that employed transgender waria in Aceh. A dozen clients and employees were arrested. Police "forced them to remove their shirts, cut their hair in public, and detained them for 72 hours...” After controversy about the raids, the local police chief responsible for the raid was transferred to a different region. ${ }^{103}$

12. 2018, July, Aceh, Indonesia.

Two men were publicly caned for gay sex on Friday, July $13^{\text {th }} .{ }^{104}$

13. 2018, September, Terengganu State, Malaysia.

Two women were given six strokes of the cane for sexual relations. There was international publicity and Prime Minister Mahathir criticized the punishment. It

98 AP, "Dozens arrested in raid on Jakarta gay sauna" Bangkok Post, May 22, 2017; AP, "141 arrested in raid on Jakarta gay sauna" Bangkok Post, May 23, 2017, 5; AFP, "Jakarta police arrest 141 men for 'gay party", The Nation (Bangkok), May 23, 2017, 5A; "Raid on alleged gay sex party not related to LGBT issues: Police” Jakarta Post, May 23, 2017; Jeffrey Hutton, “Indonesia's Crackdown on Gay Men Moves from Bars into the Home, New York Times, December 30, 2017. The New York Times story indicates that at the time of the police raid, a show with strippers was underway.

99 "Komnas HAM criticizes police of 'inhumane' raid on alleged sex party", Jakarta Post, May 25, 2017.

100 "Police raid alleged gay spa in C. Jakarta, detain 51", Jakarta Post, October 8, 2017; Reuters, "Indonesia police detain 51 men in Jakarta 'gay spa' raid”, October 8, 2017.

101 Gay Travel Asia, “Jakarta City Guide”, accessed April 28, 2020.

102 Human Rights Watch, Press release, “Indonesia: Anti-LGBT Crackdown Fuels Health Crisis” July 12018.

103 Human Rights Watch, supra note 28 at 29.

104 “Indonesia's Aceh whips gay couple for syariah-banned sex" Straits Times, July 13, 2018. 
was apparently the first use of caning for accusations of lesbian sex. The national cabinet issued a statement criticizing the punishment, saying the public caning "did not reflect the just and compassionate face of Islam" and that, "given it was their first offence, they should have been counseled and given a lighter sentence." The statement did not directly refer to LGBT or criticize the law in question. ${ }^{105}$ The actual caning took place in early 2019.

The punishment was controversial for two reasons: women had rarely been subject to corporal punishment in Malaysia, and caning had never been carried out in public before. ${ }^{106}$

14. 2018, November, Selangor State, Malaysia.

Islamic enforcement officers detained twelve males, gathered in a two-story apartment, for 'attempting' same-sex sex acts. Eleven were charged under statelevel Shariah law.

A director from the Malaysian religious department, JAIS, said that after monitoring the men on messaging app WeChat, its officials conducted a sting operation involving more than 50 law enforcement officers. ${ }^{107}$

Five pleaded guilty and were sentenced by the Selangor Syariah Court to a fine of 4,800 Ringgit, six months imprisonment and six strokes of the cane. After a trial, an additional five were sentenced to imprisonment (six months for four, seven for one), plus fines and six strokes of the cane. ${ }^{108}$ Enforcement was not the result of neighbors being offended by a loud party. What had led to the violation of privacy of online messaging? The story was so newsworthy that it was covered by the major wire services AFP and Reuters and appeared in the South China Morning Post, the Straits Times, the Star Online (Malaysia), Asia One, Nikkei Asian Review and Amnesty International press releases. What had prompted this seemingly unprecedented enforcement activism by Sharia officials? The incident is anomalous - but it was a major raid, involving 50 law enforcement officers, with eleven individuals charged and 10 men imprisoned, fined and caned. It was not the result of routine law enforcement. ${ }^{109}$

15. 2019, April, Visiting Indonesians, Penang State.

105 Tan, supra note 24 at 5 .

106 Ibid at 2. There was a crowd of around one hundred people who gathered to witness the caning. And see Human Rights Watch "Malaysia: Two Women Face Caning for Same-Sex Conduct" August 21, 2018.

107 Amnesty International, "Malaysia: Caning of four men is a terrible warning to LGBTI people, while more await trial" November 19, 2019.

108 The sentencing and the caning of the second group of five took place in November 2019. See Reuters, "Malaysia sentences 5 men to jail, caning and fines over gay sex" The Straits Times, November 7, 2019.

109 Beth Lih Yi, "Malaysian wins landmark right to challenge Muslim gay sex ban" Thompson Reuters Foundation, May 27, 2020. 
In April 2019, five Indonesian men were arrested in a hotel room in Penang State, Malaysia, for offering sex through online apps. Intelligence came from the Immigration Department Authorities, who said they could be prosecuted under immigration rules for "immoral behavior".

16. 2019, November, Visiting Vietnamese, Penang State.

An 'agent provocateur' went with two young visiting Vietnamese males to their hotel room, leading to charges of engaging in an "immoral act". The two pleaded guilty. The arrest was by the Immigrant Department, not the regular police or Sharia police. The charge was under the Immigration Rules, and both were fined 1,000 Malaysian Ringgit (US\$240). ${ }^{111}$

17. 2019, November, Prince Spa, Bangkok.

On November 7, 2019, police raided the Prince Spa, a large gay men's massage parlor in Bangkok. Police said they suspected drug use on the premises and undocumented foreigners working there. Three Thai nationals were handed over to regular police on drug charges. Six from Myanmar were arrested for illegal entry and working without a permit. Other workers were not charged. This was a typical outcome for police raids on heterosexual massage or host bar premises, where concerns are for drugs, underage workers and non-Thai workers. The Spa was ordered closed for six weeks.

18. 2020, January, Lavender Massage, Udon Thani.

On January 12, 2020, Lavender Massage in Udon Thani, Thailand, was raided by police. The owner and five male masseurs were arrested. The immigration police and the anti-trafficking division were involved, but there is no reference to finding foreign workers. No further details available.

19. 2020, January, Angelo Bali Gay Guesthouse, Indonesia.

A story broke in January 2020, of a venue called Angelo Bali Gay Guesthouse, apparently the only place to use 'gay' in its name. The Travel Gay website listed it as an "exclusively gay, clothing-optional resort" and one block from the gay bars. Its Facebook page was featured on local news outlets. It was reported to the police, who said they would investigate. Three other resorts came under police scrutiny as

110 Rik Glauert, "Malaysian police arrest five Indonesian men on suspicion of prostitution" GayStarNews, April 10, 2019.

111 Balvin Kaur, "Gay Vietnamese tourists fined for committing 'immoral act' in Penang hotel” New Straits Times, November 25, 2019; Just.Equal Media Release, "Call for Malaysia Travel Warning Following Gay Convictions” November 26, 2019. 
well. Police said that if there was proof that a resort caters to the gay community they would "temporarily seal the property". ${ }^{112}$

20. 2020, July 21, Ann Massage, Chiang Mai, Thailand.

A complaint had been lodged with the government by the anti-human trafficking Ronnasit Foundation, who alleged that Ann Massage in Chiang Mai employed underage boys. In a sting operation, a plainclothes police officer accessed the online postings of Ann Massage and visited the premises. Two 17 year old boys were introduced and available for sexual services. The manager/owner was arrested and charged. ${ }^{113}$

21. 2020, August 29, South Jakarta private party.

On Saturday, August 29, 31 police officers raided an apartment or hotel venue where 56 males were holding a private party. Information about the party had circulated on social media. Participants paid registration fees of IDR 150,000 to IDR 300,000 (US \$10 - US \$20). Nine males, who were thought to be the organizers, were charged under the Pornography Law, accused of facilitating or funding pornographic services (maximum penalty 15 years imprisonment). They were also charged under a section of the Criminal Code generally used to charge pimps. The remaining 47 were released without charge. Police said the organizers held sexually themed games during the party. "Police confiscated items such as used condoms, scrubbing cream, and sexual performance enhancers as evidence...” The organizers were said to be behind six similar events in the past, held at different venues across Jakarta. The organizers had no commercial goals, not looking to profit from the event. ${ }^{114}$

What conclusions flow from this listing of enforcement events? First, four of the nineteen stories are about foreign sex workers $(15,16,17,18)$. Anti-trafficking laws and policies in recent years have led to concerns about women crossing borders and involved in sex work, and also men. Thai gay 'host' bars and massage parlors have often had some sex workers from Myanmar, Cambodia and Vietnam. Thai Police charge and deport the foreign sex workers, without taking any action against the Thai sex workers. In case 17, the Spa was ordered closed for six weeks, a punishment to the owners for having foreign sex workers. Stories 15 and 16 show foreign male sex workers seeking business in Penang State in Malaysia. Second, two stories $(2,3)$ involve

112 Mercedes Hutton, "In Bali, LGBT businesses targeted for catering to the gay community and 'tainting tourism”" South China Morning Post, January 22, 2020. On January 24, 2020, there was no listing of Angelo Bali Gay Guesthouse on the Travel Gay website.

113 Cops arrest madam at gay sex shop, Bangkok Post, July 23, 2020, 4.

114 "Police arrest 9 men after raiding 'gay party' in South Jakarta", Coconuts Jakarta, September 3, 2020; Alya Nurbaiti, "Police lambasted for targeting LGBT community in raid in Jakarta", September 5, 2020. 
police actions that have been the result of vigilante actions, an Indonesian pattern. Third, in two stories, neighbors have complained to the police $(4,5)$, indicating that the all male events had drawn attention to themselves. In that way the events were not wholly 'private' in character. Fourth, active police and immigration department enforcers monitoring internet communications can be seen in 3 to 6 cases $(1,14,15$, and perhaps 16, 19 and 21). Internet advertising features in case 20.

One case (11) shows wholly extra-legal police actions against Waria running beauty salons in Aceh, publicly humiliating them and cutting their hair. No charges resulted, but the police chief responsible for the area was removed as a result.

Two cases involve police raids on a gay gym and a gay sauna $(8,9)$. These are Indonesian cases. They involve fairly well-known patterns of businesses catering to gay men that do not involve the commercial sale of sex and generally do not disturb neighbors. They actually serve to keep gay men out of public sight. They facilitate same-sex sexual activity, but in private settings. In recent years such premises have not been subjected to police raids and prosecutions in Singapore, Malaysia or Thailand (or other parts of Southeast Asia), unless there are allegations of drugs or underage patrons. The stories of these two cases do not indicate vigilante actions or neighbor complaints. There are no stories of follow up raids on such premises, suggesting a peaking of police activity in Jakarta in 2017, as suggested by Human Rights Watch in their comments on the raids in that year (10). The events described in cases 14 and 21 also seem completely about a private party, with no complaints from neighbors. The remaining cases have little or no information as to how the charges came about $(7,12$, 13).

One case involved underage sex workers in a commercial massage parlor and a complaint from an anti-trafficking NGO (20). Some cases involved fairly large numbers of participants. Case 14 in Selangor saw 12 arrested. Case 2 involved 13 males. Case 5 had 14. Case 9 had 51. Case 21 had 56 at an organized party (and similar organized parties had occurred in the past). Case 8 at Atlantis gym had 141 arrests. Not all those arrested were subsequently charged. The only area in Southeast Asia with consistent and ongoing enforcement would seem to be Aceh, in north Sumatra, but even their available information is limited and numbers small. Jakarta police are somewhat active. Large events attract attention.

Over time, the most common 'right' recognized in human rights decisions that have ruled against anti-homosexual criminal laws has been the right of personal privacy: see the leading decisions in Dudgeon $v \boldsymbol{U K}$, European Court of Human Rights, 1981, Toonen v Australia, UN Human Rights Committee, 1994, and Lawrence v Texas, US Supreme Court, 2003. The sexual activities in question were seen as matters of personal morality acted out by consenting adults in private settings. This runs parallel to common police practices that focus on (a) public acts of cruising or soliciting, (b) coercion, (c) underage partners or (d) activities resulting in complaints, from neighbors 
or affected third parties, of noise or congestion. Criminal law should only apply to actions that injure others.

Legislative repeal or reform of early anti-homosexual laws can be politically difficult. It is much easier to simply end any attempts at active enforcement. We can see the constitutional litigation in Singapore as an assertion of legitimacy and visibility. It is not a response to active policing.

\section{EQUALITY / NON-DISCRIMINATION}

The rights set out in the Universal Declaration of Human Rights, by Article 2, apply to everyone

"...without distinction of any kind, such as race, color, sex, language, religion, political or other opinion, national or social origin, property, birth or other status."

LGBTI are not named, but (a) the list gives examples. The list does not limit the broad prohibition of a "distinction of any kind". And (b) the provision refers to "other status" clearly indicating that matters such as disability (not named) and sexual orientation (also not named) can or should be included.

Equality and non-discrimination provisions are common in national constitutions in Southeast Asia. The Constitution of Indonesia, as one example, has both a declaration of equality (Article 28 (D) (1), and a broad non-discrimination clause, (Article 28 (I) (2). The latter reads as follows:

"Every person shall have the right to be free from discriminative treatment based upon any grounds whatsoever and shall have the right to protection from such discriminative treatment."

Nevertheless, in 2019, there were accounts of Indonesian government agencies expressly barring LGBT from employment, including with the attorney general's office. $^{115}$

Anti-discrimination provisions, whether in constitutions or laws, sometimes limit their application to listed grounds of discrimination (a 'closed list'). All lists will certainly prohibit discrimination on the basis of "sex". Some courts and authorities have ruled that discrimination on grounds of sexual orientation is a form of discrimination on the basis of "sex". This was the ruling of the UN Human Rights

115 "Indonesia attorney general's office condemned for barring LGBT recruits", Reuters, November 25, 2019; AFP "Hateful' govt hiring policy slammed", Bangkok Post, November 23, 2019, 5; "Indonesia ministries ban pregnant, LGBT job seekers: report”, AFP, November 22, 2019. 
Committee in Toonen v Australia in 1994, interpreting the International Covenant on Civil and Political Rights. ${ }^{116}$

In Europe, discrimination against transsexuals is prohibited as discrimination on grounds of sex, and contrary to the treaty establishing the European Union, under the 1996 decision of the European Court of Justice in $\boldsymbol{P}_{V} \boldsymbol{S}$ and Cornwall County Council. In April 2020 the European Court of Justice ordered a senior lawyer in an Italian law firm to pay 10,000 Euros in damages for his statement in a radio interview that he would never hire gay people because homosexuals had "physical and genetic anomalies". ${ }^{117}$

Passage of national non-discrimination laws on LGBT grounds have repeatedly failed in the US Congress. In June 2020, in Bostock ${ }_{V}$ Clayton County, the US Supreme Court ruled that job discrimination on grounds of sexual orientation or gender identity was discrimination on the basis of "sex", contrary to the 1964 Civil Rights Act, a law that covers only race and sex. The decision was authored by conservative justice Neil Gorsuch (a controversial Trump appointee) on behalf of a sixjudge majority (that included both liberal and conservative justices).

Constitutional provisions on anti-discrimination usually only apply to actions by government. Legislation is needed to extend those provisions to the private sector. An EU directive in October 2000, requires all EU member states to prohibit discrimination in employment on grounds of sexual orientation. ${ }^{118}$

The major issue in Hong Kong and the Philippines over the past number of years has been agitation for anti-discrimination laws aimed at the private sector and covering sexual orientation and gender identity. The main concern is discrimination in employment. Eighteen versions of an anti-discrimination bill were introduced in the Philippine Congress between 2001 and 2017. It has passed in the lower house, but never in the Senate. Non-discrimination laws have come into force at local levels in the Philippines. Twenty-one out of 1,634 cities and municipalities and six out of 81 provinces have such laws, covering around $20 \%$ of the national population. ${ }^{119}$ The number of local jurisdictions with such laws keeps growing. It was reported in October 2020, that the city of Zamboanga had enacted a broad anti-discrimination ordinance

116 Australia had asked the Committee to rule whether sexual orientation was included within "other status” in article 2 (1) and article 26 of the International Covenant, expecting a positive response. Instead, the Committee chose to rule on the meaning of "sex" in the list.

117 Alex Bollinger, "EU's highest court rules against lawyer who said gays 'have physical and genetic anomalies", LGBTQ Nation, April 23, 2020.

118 Parallel directives on race and sex apply more broadly, for example to accommodation and publicly available services. A move towards a 'single directive', which would treat all discrimination equally, has been debated, but remains stalled.

119 L E Yarcia, T C de Vela \& M L Tan, "Queer Identity and Gender-Related Rights in Post-Colonial Philippines” (2019) 20:1, article 19 Australian Journal of Asian Law, online: <https://papers.ssrn.com/abstract=3488543> at 7-8. 
after two years of debate. A UN report on the enactment quoted Councilwoman Lilbeth Nuno:

"We persevered and endured criticism. Yes, we retaliated. But we retaliated with education. We made them understand our purpose and what it means to be in the shoes of those oppressed."

On October 29, 2020, Manila, the capital, joined the other jurisdictions with antidiscrimination ordinances. ${ }^{121}$

In July 2003, Singapore Prime Minister Goh Chok Tong told Time Magazine that his government had begun to hire gays and lesbians. Goh said, "We are born this way and they are born that way, but they are like you and me." ${ }^{\prime 22}$ This announcement was somewhat surprising, and unprompted in the interview. He was asserting tolerance on the part of his government in an interview aimed at foreign critics of Singapore's human rights record. Singapore lacks anti-discrimination laws on sexual orientation and gender identity applicable to the private sector. Along with Brunei, Malaysia and Myanmar, it has not signed the International Covenant on Civil and Political Rights. No government in the region is known to have an official ban on government employment.

A court in Hunan province in China ordered compensation in a case where a transgender man was dismissed. ${ }^{123}$ In Taiwan, discrimination on grounds of sexual orientation in employment and education is prohibited. Macau prohibits discrimination on grounds of sexual orientation in employment. The Tokyo Metropolitan Government passed an LGBT non-discrimination law in 2018. ${ }^{124}$ Myanmar's 2018 National Youth Policy calls for the ending of discrimination based on sexual orientation and gender identity. ${ }^{125} \mathrm{~A}$ broad anti-discrimination law was submitted to the legislature in South Korea by a set of parties in June 2020. This was the seventh

120 United Nations Office of the High Commissioner for Human Rights, Equal Eyes on Our World (2020).

121 Rambo Talabong, "Isko Moreno signs Manila anti-discrimination ordinance", Rappler, October 29, 2020.

122 Hendri Yulius, Shawna Tang \& Baden Offord, "The Globalization of LGBT Identity and SameSex Marriage as a Catalyst of Neo-institutional Values: Singapore and Indonesia in Focus" in Bronwyn Winter, Maxime Forest \& Réjane Sénac, eds, Global Perspectives on Same-Sex Marriage (Palgrave Macmillan, 2018) 171 at 189. The fact of the statement being made in a prominent foreign news magazine suggests a response to ongoing international criticisms, including from business groupings, as well as a wish to avoid speaking to a local audience, where some opposition would be expected.

123 New York Times, "Transgender wins sacking case" Bangkok Post, January 4, 2017, 4; "China just prosecuted its first illegal dismissal case for trans man” Pink News, January 4, 2017.

124 Kyle Knight, "Taiwan’s Same-Sex Marriage Law Should Encourage Rights Reform Across Asia”, Human Rights Watch, May 31, 2019, 3.

125 Stiftung, supra note 12 at 3-4. Apparently, no talk of the repeal of colonial era criminal laws. 
time such a bill has been introduced. In past attempts, the inclusion of provisions on LGBTI were especially contentious. ${ }^{126}$

In Thailand, in 2007, a military installed government conducted a revision of the constitution. Activists, with strong support from the National Human Rights Commission, used the opportunity to lobby for specific inclusion of 'diverse sexualities' or 'sexual identity' in the constitution's equality provision. There was debate and three separate votes. New language was not added, but an official "intentions" document was later issued. It said that the Thai term 'phet', used in the particular constitutional provision, usually translated as 'sex' or 'gender', covered "the differences between individuals in sexual identity or gender or sexual diversity, which may be different from the phet in which the person was born..." In other words, in the view of the constitutional drafters, LGBTI were already covered by the constitutional provision. Additional language was not necessary. ${ }^{127}$

The Thai Gender Equality Act (GEA) was enacted in March 2015, and officially launched at a public event in September 2015. Individuals associated with the Thai Transgender Alliance and Rainbow Sky (the leading gay-run health and rights NGO) are members of the Committee on the Consideration of Unfair Gender Discrimination established under the act. When General Prayut, head of the military government, spoke at the UN General Assembly, he specifically mentioned the Gender Equality Act as an accomplishment of his government. ${ }^{128}$

The $\boldsymbol{G E A}$ is the legislative implementation of the 'phet' equality provision in the constitution, including the elaboration in the 'intentions' statement. ${ }^{129}$ But the government justified the legislation as fulfilling "the principles of universal human rights, according to the international conventions to which Thailand is a signatory."

On a finding of unfair gender discrimination, an order made under the Gender Equality Act can require government agencies, private organizations or individuals to take remedial action. Failure to comply can result in criminal charges. ${ }^{131}$ The process has proven to be slow and bureaucratic.

There have been certain specific, well-publicized cases of discrimination against transgender women in Thailand. In 2007 Sutthirat Simsiriwong was barred from

126 "South Korea: New anti-discrimination bill offers 'hope' to LGBTI community", Amnesty International UK Press Release, 16 July 2020.

127 Douglas Sanders, “The Rainbow Lobby" in Peter A Jackson, ed, Queer Bangkok: Queer Asia (Hong Kong: Hong Kong Univ. Press, 2011) 229 at 240-4.

128 Prayut Chan-O-Cha, "PM lauds partnership to tackle inequality", Bangkok Post, September 29, 2015, 11.

129 Department of Women's Affairs and Family Development, UNDP, Legal Gender Recognition in Thailand: A Legal and Policy Review (2018) at 28-29.

130 Translation of the government statement by Dr Peter Jackson, personal communication.

131 Ibid, 29-30. 
entering a night club in a Novotel Hotel. The hotel management publicly apologized. ${ }^{132}$ Transwomen were excluded from parades organized by the Chiang Mai provincial government. In 2010 the Administrative Court ruled in their favor citing the 'intentions' document. ${ }^{133}$

Kathawut Khangpiboon, a transwoman and one of the founders of the Thai Transgender Alliance, had been a contract lecturer at Thammasat University for five years. In June 2014, she was offered a permanent position. The university then rescinded the job offer, saying that Kathawut had used inappropriate language and postings on social media. The Rector said a posted photo of a penis-shaped lipstick, an amusing gift, was a sign of Kath's improper conduct online, indicating that she would not be a good teacher. ${ }^{134}$ In 2018 the Administrative Court ruled that the social media postings had no bearing on her qualifications. Thammasat was ordered to hire her and the university complied. ${ }^{135}$ The scandalous tube of lipstick was a featured item in the Museum of Siam's LGBT history show that opened in May 2018.

In 2013 the Supreme Court of India held that the prohibition of discrimination on grounds of "sex" in the Constitution of India covered "gender identity," which required recognition of transgender hijra as having equality rights. ${ }^{136}$

Anti-discrimination laws are largely symbolic, promotional or educational. Most employers are unlikely to expressly reject applicants on grounds of sexual orientation. Many individuals will not challenge a rejection, for that would require that they be open about their sexual orientation. Nevertheless, the existence of a law helps bring about change.

In parts of the West there is support for various exemptions from laws banning discrimination against LGBTI. The US Supreme Court has upheld a right to discriminate against LGBTI, by the Boy Scouts organization and by organizers of St Patrick's Day parades, on grounds of freedom of association, overriding local laws prohibiting discrimination in the private sector on LGBTI grounds. Decisions in the US and the UK have upheld the refusal of service by bakers and wedding planners when potential customers were planning same-sex weddings. At the time of writing, the matter is again before the US Supreme Court and, for the first time, at the European Court of Human Rights.

132 Sexual orientation, gender identity, and justice: a comparative law casebook, by International Commission of Jurists (2011) at 239.

133 Ibid at 165.

134 Sasiwan Mokkhasen, "Thammasat cites risqué lipstick for rejecting transgender prof" Khaosod English, October 14, 2015; Melalin Mahavongtrakul, "It's that time of year" Bangkok Post, April 30, 2015.

135 Chularat Saengpassa, "Thammasat ordered to rehire transgender lecturer” The Nation (Bangkok), March 9, 2018, 1A.

136 The decision was relied on by the Court of Appeal in Malaysia in Muhamad Juzaili Bin Mohd Khamis $v$ Negeri Sembilan in 2014 for transgender Mak Nyah (a decision reversed by the Federal Court on procedural grounds). 
Ahmed Shaheed, UN Special Rapporteur on Freedom of Religion and Belief, in his February 2020, report to the Human Rights Council, commented:

"The Special Rapporteur rejects any claim that religious beliefs can be invoked as a legitimate 'justification' for violence or discrimination against women and girls or against people on the basis of their sexual orientation or gender identity. International law is clear that the manifestation of religion or belief may be limited by States, in full conformity with the criteria outlined in Article 18(3) ICCPR, to protect the fundamental rights of others, including the right to nondiscrimination and equality, a principle upon which all human rights, including the right to freedom of religion or belief depends." ${ }^{137}$

\section{TRANSGENDER}

Article 12 (1) of the International Covenant on Economic, Social and Cultural Rights recognizes the right of everyone "to the enjoyment of the highest attainable standard of physical and mental health." The two established international systems cataloging particular mental conditions are the Diagnostic and Statistic Manual of Mental Disorders, DSM, of the American Psychiatric Association and the International Classification of Diseases, ICD of the World Health Organization. Panels of medical experts, who have been responsible for revisions to these authoritative documents, have struggled in recent years with the proper terminology to describe the condition of individuals whose sense of sex or gender is at variance with the physical characteristics that at birth identified them as male or female. A currently favored term is "gender dysphoria." A diagnosis of "gender dysphoria" leads to a decision on an appropriate medical response in the individual case. As with a number of human conditions, there is no 'cure', but treatment can strengthen the individuals' physical and mental wellbeing. In particular cases genital reconstruction surgery is an appropriate medical response (called sex reassignment surgery or gender confirmation surgery). The World Professional Association for Transgender Health has issued a set of standards that have been widely followed for diagnosis and treatment, including counseling, surgery and hormonal support.

There is no necessary relationship between transgenderism and sexual orientation. A transgender individual may be lesbian, gay, bisexual or asexual. Most male-to-female transgender individuals are attracted to men and seek what they identify as a heterosexual relationship. Their inclusion with homosexuals in the LGBTI formulation is part of a coalition strategy. Each of the groupings identified within LGBTI face issues of discrimination and marginalization on grounds of sex and gender diversity. In our time, they work together to secure change.

137 A/HRC/43/48. 27 February 2020, paragraph 70. 
In the first court cases on transgender rights, individuals who had undergone genital surgery, and who were living in their desired sex, sought to gain personal documents, such as passports, national identity cards and drivers' licenses, that showed their new appearance and identity. The European Court of Human Rights in 2002 ruled in Goodwin v $\boldsymbol{U K}$ that a post-operative male-to-female transsexual was entitled to gain document change, allowing her marriage to a male.

The change of the designation of 'sex' (male or female) on documents such as passports, national identity cards and birth certificates is possible in Asia in Mainland China, Hong Kong, Indonesia, Japan, Korea, Singapore and Taiwan. In the Muslim world, change is possible in Egypt, Indonesia, Iran and Turkey, but not Malaysia. It is said that getting document change in Indonesia, by court order, is so difficult and expensive that almost no one attempts to get the change. A Hong Kong decision in January 2019, supported the government policy of requiring full genital surgery before document change would be allowed. ${ }^{138}$

The requirement of genital surgery was dropped by the United Kingdom in the 2004 Gender Recognition Act, but a medical assessment was still required and approval by a government established board. More recent reforms in the west, led by Argentina in 2008, have ended both the need for surgery and a medical diagnosis for document change. Government is to recognize the 'self-determination' of the individual. Changing 'sex' on personal documents in Argentina and some other countries has become a simple administrative procedure. This kind of reform has not yet taken place in Asia. In the west it is limited to countries that have opened marriage to same-sex couples.

The National Fatwa Council in Malaysia banned 'gender affirming' surgery in 1982. ${ }^{139}$ The doctor who performed such surgery in Singapore retired and has not been replaced. Thailand has many hospitals and clinics that provide good quality 'gender affirmation' surgery. In international terms the costs are reasonable. Many clients come from outside the country. Whether document change will follow back home is a matter for the home country jurisdiction. Thailand itself does not yet allow document change. At the moment government officials are in a drafting process for a gender identity law, working with the Thai Transgender Alliance. ${ }^{140}$

The state of Negeri Sembilan in Malaysia, like other states, has a Shariah law that prohibits any Islamic male from wearing women's clothing or posing as a woman in a public place. Three individuals challenged the law on constitutional grounds. They had been repeatedly detained, arrested and prosecuted by the religious authorities for

138 The case is Tse, $Q$ and $R_{v}$ Hong Kong, and the decision of the trial level court is said to be under appeal. See "Hong Kong: Transgender people must have full sex change surgery to switch gender on gov't ID, court affirms” Equal Eyes, February 1, 2019.

139 Shannon Power, "Muslim cleric calls for changes to fatwa against trans people in Malaysia" GayStarNews, February 16, 2018.

140 Thana Boonlert, "Gender recognition bill set to be tabled", Bangkok Post, August 3, 2020, 3. 
cross-dressing. An expert witness gave evidence that cross-dressing by males is prohibited by Islam. For the defense, a psychiatrist and two psychologists gave evidence on the medical classification of "gender identity disorder", the phrase then in use in the DSM. The evidence established that the three individuals had been diagnosed as having gender identity disorder, and that it was neither a matter of personal choice nor amenable to treatment. As a result, "they feel natural" in expressing themselves as women. The medical evidence was supplemented by that of a Malaysian sociologist. Supporting briefs were filed by the Malaysian Bar Council and the International Commission of Jurists. The Court of Appeal ruled in November 2014, that Sharia laws, like any other laws, were subject to the human rights provisions in the national constitution. It found the application of the Sharia law to individuals with gender identity disorder violated a number of constitutional provisions. It ruled that the protection of the "life and liberty" of the person includes "the right to live with dignity" which the particular law denied to these individuals. The court cited the recent decision of the Supreme Court in India, National Legal Services Authority v Union of India, which held that the prohibition of discrimination on grounds of "sex" in the Indian Constitution covered "gender identity." The judgment criticized the trial judge's comments equating the petitioners with homosexuals. The judgment separated sharply the categories of sexual orientation and gender identity, saying the case had "absolutely nothing to do with homosexuality."

Early in 2016, the Federal Court, the highest appeal court, ruled on procedural grounds that the decision of the Court of Appeal was improper. A constitutional challenge to any law, it said, required leave from the Federal Court before it could proceed. The Shariah law is back in effect. Judicial review on constitutional rights grounds of any state level Sharia system can be blocked. ${ }^{141}$

\section{XII. 'THIRD SEX' GROUPINGS}

In parts of Asia there are locally recognized transgender groupings that are understood to be separate from the binary categories of men and women. For lack of a better term, they are considered 'third sex' groupings. The largest and most institutionalized such groupings are the Hijra, and parallel groups, in India, Pakistan and Bangladesh. ${ }^{142}$

In Southeast Asia the groupings are somewhat different, but still distinctive. They are the Bakla in the Philippines, Mak Nyah in Malaysia, Waria in Indonesia and Kathoey in Thailand, Laos and Cambodia. ${ }^{143}$ They are male by birth, though some may be intersex. They present as women. They commonly run beauty salons or work as

141 Sanders, supra note 25 at 122-123.

142 The Metis in Nepal do not have the collective organizational patterns of Hijra in India, Pakistan and Bangladesh. In this they are similar to Southeast Asia examples.

143 In Myanmar there is a category of Open individuals, who are biological males who present as women. 
clerks or waitresses. Some are entertainers and some sex workers. No equivalent named groupings are found in the Confucian influenced areas of China, Japan, Korea, Singapore, Taiwan and Vietnam, where transgender individuals follow individual identity patterns, as in the West.

Welfare programs for third sex groupings have developed in India, Pakistan and, at times, in Indonesia and Malaysia. This identifies the groupings as socially and economically marginal, in need of training and assistance (with some extent of job reservations in India). Some in Indonesia have been given training on running beauty salons by the ministry of social welfare.

There have been some moves to recognize a third gender in documents. Instead of $\mathrm{M}$ or $\mathrm{F}$, there might be an $\mathrm{X}$ or another marker. National voter registration cards in India, as one example, have three possibilities for the designation of 'sex'.

The leading example of recognition of third sex groupings in South Asia came in the April 2014, decision of the Indian Supreme Court in National Legal Services Authority ${ }_{V}$ Union of India. The Court ruled that Hijra should be recognized as a third gender and not only enjoy all fundamental rights, but also receive special benefits in education and jobs to overcome historic discrimination. ${ }^{14}$ Assessments of the implementing legislation passed in India in 2019 and parallel developments in Pakistan and Bangladesh are beyond the scope of the present paper.

\section{RECOGNIZING SAME-SEX RELATIONSHIPS}

Article 23 of the International Covenant on Civil and Political Rights deals with marriage and family. It provides that

"...the right of men and women of marriageable age to marry and to find a family shall be recognized.”

The Human Rights Committee, established pursuant to the Covenant, has interpreted the provision as dealing only with heterosexual marriage. But it has ruled that same-sex couples should be treated equally in matters of specific rights (with decisions supporting survivor pension rights in cases from Australia and Colombia). The European Court of Human Rights has ruled that the European Convention on Human Rights requires states to have at least a registration system providing spousal rights and obligations. ${ }^{145}$ The Inter-American Court of Human Rights has ruled that states must provide equal access to full legal marriage. ${ }^{146}$

\section{What is happening in Asia?}

144 Human Rights Watch, "India: Enforce Ruling Protecting Transgender People” February 5, 2015.

145 Oliari v Italy, July 2015.

146 "Decision on reference by Costa Rica", January 2018. 
There are some 'do-it-yourself' steps that can be taken. Same-sex couples can use wills, powers of attorney, joint ownership and legal guardianship laws to create a limited legal framework for their relationships.

In 2017 a guidebook was published in Singapore titled Same But Different. In 156 pages, it sets out the legal framework possible for same-sex couples using existing laws. ${ }^{147}$ In Cambodia, an LGBTI NGO has drawn up a model document, the Declaration of Family Relationship, as a civil contract to deal with property issues and childcare. It has been publicized throughout the country. Colorful ceremonies have been held for groups of couples to celebrate signing their declarations. ${ }^{148}$ In China same-sex couples can become each other 'legal guardian', through a process at a government notary office. This secures property rights and the ability to make medical decisions in cases where the partner's ability is impaired. The arrangement has been possible since 2017, when it was no longer restricted to the elderly. ${ }^{149}$ It is rather expensive. Notaries like the extra income.

\section{a. Registration (as evidence of a relationship)}

Sometimes existing family registration systems have been opened to same-sex couples simply to allow them to create a formal record of their relationships, without any specific grant of rights.

In Taiwan, same-sex couples were able to register in the country's household registration systems, beginning in 2015 in Kaohsiung. Such registration is possible in Japan in 26 municipalities and one prefecture, covering about $14 \%$ of the population. The local governments in Japan will issue 'partnership certificates' which may be useful for hospital visitation rights or subsidized housing. Included are the cities of Fukuoka, Osaka, Sapporo and Yokohama. ${ }^{150}$ This innovation started in two wards within greater Tokyo, Shibuya and Setagaya, in 2015. Such registrations do not themselves provide any legal rights but may be recognized as proof of a relationship by local governments or medical and other institutions or programs.

\section{b. Recognition of same-sex cohabitation}

147 Indulekshmi Rajeswari, Same but different:a legal guidebook for LGBT couples \& families in Singapore (Singapore, 2017).

148 Shannon Power, "Same-sex couples tie the knot in Cambodia in a stunning public ceremony" GayStarNews, May 24, 2018.

149 Mandy Zuo," Gay couple in Beijing become first to take advantage of new legal rights" South China Morning Post, August 9, 2019; Jiayun Feng, "Same-sex couples in mainland China are naming their partners as legal guardians" Supchina, August 5, 2019; Jiayun Feng, "Beijing approves first guardianship case for same-sex couple” Supchina, August 9, 2019; Matthew Strong, "Gays in China push for guardianship agreement as result of Taiwan progress” Taiwan News, August 27, 2019.

150 Kyodo, "Yokohama begins distributing papers recognizing LGBT and common-law couples" Japan Times, December 2, 2019. 
In Vietnam the Ministry of Justice proposed the legal recognition of same-sex cohabiting couples for purposes of managing disputes over property and children, part of a set of amendments to the marriage law. The particular measure was defeated in the legislature. Japan recognizes "de facto marriages" for cohabiting heterosexual couples, on a case-by-case basis, but not for tax or inheritance. In March 2020, the Tokyo High Court, in the first such published decision, recognized the "de facto marriage" of a lesbian couple. ${ }^{151}$

\section{c. Recognition of foreign same-sex marriages}

Legal foreign same-sex marriages may convince courts that particular relationships deserve recognition. Decisions of the courts in Hong Kong have referred to foreign legal same-sex relationships (a UK civil registration, a NZ marriage, a Canadian marriage) in decisions granting (a) a dependant visa, giving a partner residency and a right to work (b) medical and other employment benefits for the foreign partner of a Hong Kong civil servant ${ }^{152}$, and (c) an entitlement to subsidized housing for low-income families. The Court of Appeal in Thailand in 2019 recognized a British same-sex civil registration in making a Thai citizen the executor/ administrator of the estate of his deceased British partner.

\section{d. Civil unions, registered partnerships}

Many jurisdictions in the West now have registration laws granting specific rights to same-sex couples who register. Such laws began in Denmark in 1989. The Danish law granted most of the rights and obligations of marriage to same-sex couples who registered. The law avoided the term 'marriage' and did not include rights to adopt children. That came later. One partner needed to be a Danish citizen or permanent resident. Registration systems were put in place in many other jurisdictions after the Danish lead, some called civil unions, registered partnerships or other names.

A draft 'life partnership' registration bill, with limited rights, was given initial approval by the Thai cabinet in December 2018, and passed to the Council of State, an elite French-inspired advisory body, for assessment. After a very unusual 18-month period of closed-door discussions and negotiations, a much stronger bill emerged, now including adoption rights equal to those of married couples. It got cabinet approval in

151 Nippon.com, "Tokyo High Court backs legal coverage for same-sex partnership” March 4, 2020; Tatsumi Kenji, Akira Hattori, "Tokyo court rules same-sex common-law couples has marriage legal protections" The Mainichi, March 5, 2010. "De facto" seems the better English language translation of the Japanese terminology, rather than "common law". The ruling could lead to support/maintenance obligations towards a partner who has become dependent in the relationship.

152 These decisions of the Court of Final Appeal found that the foreign legal recognition was evidence of a stable same-sex relationship that deserved recognition on equality grounds. 
July $2020 .{ }^{153}$ The most obvious inequality remaining is the rejection of spousal benefits connected with employment. The Ministry of Finance kept asking how many homosexuals lived in the country, concerned with the possible costs of spousal benefits for partners of civil servants. Perhaps, they said, they would need a special budgetary line item to cover these new costs but had to be told how many claimants to expect. That successfully blocked an inclusion of spousal benefits for the moment. Opposition legislators have introduced a competing bill, which would amend the Civil Code to open the existing marriage law to same-sex couples. The two bills may be considered in the legislature at some point in 2021.

A registration bill has been introduced into the legislature in the Philippines, but not yet enacted. It was introduced by Geraldine Roman, the first elected transgender legislator in a national government in Asia. Philippines President Duterte "has long expressed support to same-sex civil unions", but action is necessary by the legislative branch. ${ }^{1.54}$

\section{e. Marriage}

Court cases seeking the opening of legal marriage have taken place or have begun in Mainland China, Hong Kong, India, Japan, Korea, Philippines and Taiwan. Courts have rejected same-sex marriage cases in China, Hong Kong, Korea and the Philippines. Of these, the only decision of the highest court was in the Philippines in September 2019, dismissing the case on procedural grounds and deferring to the legislative branch of government.

The Constitutional Court in Taiwan upheld equal marriage rights in 2017, and legislation implementing the decision was enacted in 2019. ${ }^{155}$ Taiwan was the first jurisdiction in Asia to open marriage to same-sex couples, and the $29^{\text {th }}$ internationally. As of 2020, the following jurisdictions have opened legal marriage to same-sex couples:

"Argentina, Australia, Austria, Belgium, Brazil, Canada, Colombia, Costa Rica, Denmark, Ecuador, Finland, France, Germany, Iceland, Ireland, Israel (for foreign marriages), Luxembourg, Malta, Mexico (some parts), Netherlands, New Zealand, Norway, Portugal, South Africa, Spain, Sweden, Taiwan, United Kingdom, United States (with

153 Mongkol Bangprapa, King-Oua Laohong, "Civil unions for gay couples”, Bangkok Post, July 9, $2020,2$.

154 AP, "Mixed Philippine reaction on pope nod on gay civil unions", Washington Post, October 22, 2020. The quotation is identified as coming from the official spokesman of the president.

155 There are three limitations or qualifications in the Taiwanese law. It is not an amendment of the Civil Code on marriage, but a completely separate law. Secondly adoption of children by the couple is not allowed - only second parent adoption, when a child is the biological child of one partner. Thirdly, marriage is only possible with a foreign partner, when that partner is from a country where same sex marriage is recognized. Foreign same-sex couples cannot fly in and get married. One partner at least must be Taiwanese. 
the exception of American Samoa and some Native American tribal governments) and Uruguay."

A bill to amend the Japanese Civil Code to make the marriage provisions gender neutral was introduced in the national Diet on $3^{\text {rd }}$ June 2019, supported by the Constitutional Democratic Party and other opposition parties. ${ }^{157}$ The Japan Federation of Bar Associations supports equal legal marriage.

A Chinese court in Changsha, Hunan province, heard a case arguing for same-sex marriage in $2016 .{ }^{158}$ While the claim failed, it seemed remarkable to many that the case could be heard at all. The couple who mounted the case launched an NGO, the Family Equality Network. The Network website has posted its draft of a gender-neutral version of the existing family law. In six months, it gained 7,000 online signatures for the reform. ${ }^{159}$

In 2019 China's top legislative body invited submissions on reform of the Civil Code.

"It received an avalanche of submissions, with nearly 200,000 people sending feedback in one month. Over 190,000 of them made the same proposal: Legalize same-sex marriage. It was so overwhelming that officials publicly acknowledged legalizing gay marriage was among the most popular suggestions they had received during a Dec. 20 press conference." 160

Soon after there was a public 'wedding' of four same sex couples in Wuhan in an event organized by the local PFLAG group. ${ }^{161}$ Two hundred attended.

\section{f. Rights in relation to children:}

What are the implications of these varied systems in relation to rights regarding children? It seems that nowhere in Asia can a same-sex couple secure joint legal custody for a child the couple is raising. The one exception is limited to second parent

156 Journalist and blogger Rex Wockner follow developments and updates the list of countries with equal marriage. See rexwockner.com, or wockner2blogspot .com/2018/09/worldwide-on-marriageequality-watch-list.html.

157 Wikipedia, "Recognition of same-sex unions in Japan” accessed December 17, 2019.

158 “China’s First Ever Gay Marriage Rights Case Unsuccessful” Sixth Tone, April 13, 2016; Tom Phillips, "China Court Refuses to Allow Gay Marriage in Landmark Case” The Guardian, April 13, 2016. An appeal also failed.

159 Elaine Jeffreys \& Pan Wang, "Pathways to Legalizing Same-Sex Marriage in China and Taiwan: Globalization and 'Chinese Values"' in Bronwyn Winter, Maxime Forest \& Réjane Sénac, eds, Global Perspectives on Same-Sex Marriage (2018) 197.

160 Fan Yiying, "Amid the Epidemic, a Quiet Leap Forward for China's LGBT Community" Sixth Tone, February 19, 2020.

161 PFLAG, Parents and Friends of Lesbians and Gays, originally founded in the US, has chapters in Asia, notably in China and Vietnam. 
adoption in Taiwan, in cases where the child is the biological child of one partner in a same-sex marriage. Concern with the situation of children who are already being raised in same-sex households has become a reason for supporting the opening of same-sex marriage. ${ }^{162}$

A number of stories in Asia have involved surrogacy services for gay couples. Such services seem currently banned for same-sex couples in all Asian jurisdictions. ${ }^{163}$

In December 2019, the Singapore High Court allowed a Singapore citizen to legally adopt his biological child, conceived with an anonymously donated egg, and carried to term by a surrogate in the United States. The child has US citizenship, and had been granted temporary dependency status in Singapore, where the biological father lives with a long-term same-sex partner. Lawyers for the Singapore government argued that public policy favored children being raised in heterosexual married families and rejected support for same-sex couples. The Singapore judges ruled that it was in the best interests of the child to gain a secure status in Singapore with his biological father. ${ }^{164}$

\section{INTERSEX}

UN human rights concerns include issues relating to the treatment of intersex individuals. ${ }^{165}$ Intersex is an umbrella term used to describe a wide range of bodily variations in the physical sexual characteristics of individuals. Between 0.05 and 1.7 percent of the population is born with intersex traits. These may be evident at birth or may emerge at puberty - or be detected later in life. A major concern is with so-called 'normalizing surgery' performed on young babies in an attempt to bring the body as close to a 'male' or 'female' model as possible. In these cases, the surgery is not medically necessary, but 'cosmetic' in character. Such surgery brings irreversible

162 Some 319,000 children were living with same-sex parents in the United States in 2018: Wendy Wong, "A Portrait of Contemporary Family Living Arrangements for U.S. Children” Institute for Family Studies, April 14, 2020.

163 In February 2020, the Israeli High Court extended surrogacy rights to single men and gay couples. The Middle East is part of Asia. The law strictly limiting surrogacy in India failed to pass in the upper house, and a new bill is in the process of enactment in mid-2020: See Annie Banerji, "India eases planned surrogacy curbs after criticism” Reuters, February 26, 2020. In the meantime, commercial surrogacy is still legal.

164 Kok Xing Hui, "Singapore allows gay couple to adopt their surrogate son in landmark ruling" South China Morning Post, December 17, 2018; Straits Times, Asia News Network, "Singapore gay couple allowed to adopt child in landmark case" The Nation (Bangkok), December 18, 2018, 5A. Singapore authorities said they would try to close this loophole with its de facto recognition of a same-sex family relationship. Shannon Power, "Singapore is tightening adoption laws after gay man adopts surrogate son” GayStarNews, January 14, 2019.

165 Information in this section comes from OHCHR, "Background Note on Human Rights Violations against Intersex People”, online: <https://www.ohchr.org/EN/Issues/Discrimination/ Pages/BackgroundViolationsIntersexPeople.aspx>; United Nations, supra note 4. 
changes to the physical body of the child. It assigns a 'sex', male or female, though it is impossible to predict at an early age whether the child will later identify as male or female or as intersex. 'Normalizing surgery' is now referred to by intersex activists and NGOs as 'intersex genital mutilation'. The surgery may produce scarring, loss of sexual sensation, incontinence, sterilization and later psychological trauma. The individual should be given any necessary care but left able to make informed decisions on any further treatment (and about personal identity) when of age.

Having intersex characteristics is unrelated to sexual orientation or gender identity, again showing how the LGBTI acronym represents a coalition of differing groups, each of which face discrimination and marginalization on grounds of particular sex and gender characteristics.

The UN Special Rapporteur on Torture and Other Cruel, Inhuman or Degrading Treatment or Punishment in a report in 2013 condemned non-consensual treatment. A joint report by the World Health Organization and five UN agencies, including the Office of the High Commissioner for Human Rights, in May 2014, condemned the sterilization of intersex children by 'normalizing surgery'. ${ }^{166}$

In April, 2015 Malta, in pioneering legislation, outlawed non-consensual medical interventions on intersex individuals. ${ }^{167}$ The Madras High Court (Madurai Bench) in January 2016 ordered the local government to prohibit medically unnecessary 'normalizing' surgeries on children until the individuals themselves could give an informed authorization. ${ }^{168}$ The Parliamentary Assembly of the Council of Europe in 2017 and the European Parliament in 2019 passed resolutions against 'normalizing surgery. ${ }^{169}$ Four well publicized lawsuits against medical practitioners, for particularly striking examples of surgical interventions on intersex patients, have resulted in awards of damages in three instances and an out-of-court settlement in another. ${ }^{170}$ General laws against discrimination now include intersex or 'sex characteristics' as listed prohibitory grounds in Australia, Bosnia-Herzegovina, Greece, Malta and South Africa.

Little information is available on the treatment or recognition of intersex individuals in Southeast Asia. In Thailand an existing procedure allows an intersex individual to change the designation of 'sex' on their birth certificate (choosing male or

166 Eliminating forced, coercive and otherwise involuntary sterilization, by OHCHR et al (WHO, 2014) publisher: World Health Organization.

167 Kyle Knight, "Dispatches: Malta’s inspiring gender recognition law” Human Rights Watch, April 1, 2015. The law deals with transgender and intersex individuals and counters surgical practices that have no medical purpose, without full and free adult consent.

168 Kyle Knight, “Court bans 'normalization' of intersex children”, Asia Times (2019), online: <https://asiatimes.com/2019/04/court-bans-normalization-of-intersex-children/>. "The consent of the parent cannot be considered as the consent of the child,” Justice Swaminathan's ruling stated plainly.

169 Ibid.

170 Wikipedia, "Intersex Human Rights" accessed April 23, 2020. Two cases occurred in Germany and one each in Chile and the United States. 
female), if the individual had been diagnosed at birth as intersex and had been subjected to 'normalizing' surgery. ${ }^{171}$

The first Asian Intersex Forum was held in Bangkok in February 2018, with representatives from ten Asian jurisdictions, including the ASEAN states of Indonesia, Myanmar, Philippines, Thailand and Vietnam. It officially founded Intersex Asia. ${ }^{172}$

\section{CONCLUSION}

The recognition of LGBTI human rights, by the United Nations and regional intergovernmental human rights systems in Europe and the Americas, has been important in legitimating the issues discussed in this paper. In much of Asia, these developments are not well known. The UNDP program Being LGBTI in Asia, for example, almost never got coverage in regular media in the region. The $U N$ Free and Equal campaign is equally unknown. It is as if these programs never happened. Visibility comes more from publicity around HIV/AIDS (a negative story, but no longer a focus) and currently around the issue of same-sex marriage (very polarizing, but a positive story in terms of how same-sex couples are depicted).

Intolerance is vocal on the part of elites in a few places (Indonesia and Malaysia are clear examples). India and China are not in the vocally hostile camp these days. Tolerance and acceptance are rarely expressed, but seem to be advancing (think of Cambodia, Hong Kong, India, Japan, Philippines, Taiwan, Thailand, Vietnam). Regional intergovernmental organizations in Asia (ASEAN, SAARC) do not touch LGBTI issues. National human rights commissions, where they exist, are supportive. Regional human rights non-governmental organizations are vocal. International NGOs, notably Human Rights Watch, are effective in Asian coverage. Some regular Asian media get good marks for coverage (South China Morning Post, Bangkok Post). There are now six 'out' elected politicians in national legislatures (a small number in vast Asia, but a recent change). There has been a notable positive change in government policies in relation to transgender, but almost exclusively in South Asia.

In most places in Southeast Asia there has been some degree of progress. Change is occurring.

171 UNDP, DWA (2018) 59-61.

172 See www. intersexasia,org, or facebook @InternetAsia. The February 11, 2018. Public Statement by the Asian Intersex Movement was also made available on the website of ILGA Asia. 


\section{BIBLIOGRAPHY}

Media reports are cited in footnotes only.

Asian Institute of Journalism and Communication, "Courts for Muslims: A Primer on the Philippine Shari'a Courts” 12.

Buehler, Michael, The Politics of Shari'a Law: Islamist Activists and the State in Democratizing Indonesia. (Cambridge University Press, 2016).

Currier, Ashley \& Julie Moreau, "Understanding Same-Sex Marriage Debates in Malawi and South Africa” in Bronwyn Winter, Maxime Forest \& Réjane Sénac, eds, Global Perspectives on Same-Sex Marriage (Palgrave Macmillan, 2018) 81.

Cocks, Harry, "Secrets, Crimes and Diseases" in Matt Cook, Robert Mills \& Randolph Trumbach, eds, A gay history of Britain: love and sex between men since the Middle Ages (Oxford: Greenwood World Pub, 2007) 109.

Department of Women's Affairs and Family Development, UNDP, Legal Gender Recognition in Thailand: A Legal and Policy Review (2018).

Flores, Andrew R, Social Acceptance of LGBT People in 174 Countries: 1981-2017 (Williams Institute, UCLA School of Law, 2019).

Freeman, Cody \& Timo Ojanen, Discussion Paper on Empowerment and Capacity Development for Parents of LGBTI Persons in Asia, by Cody Freeman \& Timo Ojanen (ILGA Asia et al, 2019).

Gevisser, Mark, The Pink Line: The World's Queer Frontiers, main edition ed (UK: Profile Books, 2020).

Hamid, Ahmad Fauzi Abdul, "The return of old-style Malay-centric politics?” (2020) East Asia Forum (Canberra), online: <https:/www.academia.edu/42848717/ The_return_of_old_style_Malay_centric_politics_East_Asia_Forum_Canberra_25 _April_2020_URL_https_www_eastasiaforum_org_2020_04_25_the_return_of_ol d_style_malay_centric_politics_>.

Hasan, Nurdin, “Aceh Lawmaker: Activists shouldn't make fuss about shariah for nonMuslims”, (2014), online: Asia Pasific Solidarity Network <https:/www.asia-pacificsolidarity.net/index.php/news/2014-09-24/aceh-lawmaker-activists-shouldnt-makefuss-about-shariah-non-muslims.html>.

_- "To stone or not to stone: It's a matter of interpretation", (2009), online: Asia Pasific Solidarity Network <https://www.asia-pacific-solidarity.net/news/2009-1123/stone-or-not-stone-its-matter-of-interpretation.html>.

Human Rights Watch, "Scared in Public and Now No Privacy: Human Rights and Public Health Impacts of Indonesia's Anti-LGBT Moral Panic”, (2018), online: Human Rights Watch <https://www.hrw.org/report/2018/07/01/scared-public-andnow-no-privacy/human-rights-and-public-health-impacts $>$. 
International Commission of Jurists, Sexual orientation, gender identity, and justice: a comparative law casebook, by International Commission of Jurists (2011).

Jeffreys, Elaine \& Pan Wang, "Pathways to Legalizing Same-Sex Marriage in China and Taiwan: Globalization and 'Chinese Values"' in Bronwyn Winter, Maxime Forest \& Réjane Sénac, eds, Global Perspectives on Same-Sex Marriage (2018) 197.

Knight, Kyle, “Court bans 'normalization' of intersex children”, Asia Times (2019), online: <https://asiatimes.com/2019/04/court-bans-normalization-of-intersexchildren/>.

Langlois, Anthony, "No regional pattern: LGBTIQ rights and politics in Asia" in Varennes de Fernand \& Gardiner M Christie, eds, Routledge handbook of human rights in Asia (Abingdon, Oxon: Routledge, 2019) 322.

Larsson, Tomas, "Secularisation, Secularism and the Thai State" in Pavin Chachavalpongpun, ed, Routledge Handbook of Contemporary Thailand (Routledge \& CRC Press, 2020) 278.

Leach, Anna, "Why is Taiwan the best place to be gay in Asia?", GayStarNews (12 November 2012), online: <https://www.gaystarnews.com/article/why-taiwan-bestplace-be-gay-asia121112/>.

LeDoux, Philippe, Gay Sex Still a Crime in Singapore Thanks to Dubious Legal Rulings, by Philippe LeDoux (Human Rights Watch, 2020).

Manalastas, Eric Julian et al, "Homonegativity in Southeast Asia: Attitudes towards lesbians and gay men in Indonesia, Malaysia, the Philippines, Singapore, Thailand and Vietnam” (2017) 17:1 Asia-Pacific Social Sciences Review 25-33.

Mohamad, Maznah, "Politicization of Islam in Indonesia and Malaysia: Women's Rights and Inter-Religious Relations" in Theresa Devasahayam, ed, Gender Trends in Southeast Asia (Singapore: ISEAS-Yusof Ishak Institute, 2009).

Narrain, Arvind, "Vacillating between empathy and contempt: the Indian judiciary and LGBT rights" in Nancy Nicol et al, eds, Envisioning Global LGBT Human Rights: (Neo) colonialism, Neoliberalism, Reistance and Hope (London: SAS Publications, 2018).

OHCHR, "Background Note on Human Rights Violations against Intersex People", online: <https://www.ohchr.org/EN/Issues/Discrimination/Pages/BackgroundViola tionsIntersexPeople.aspx>.

—, Eliminating forced, coercive and otherwise involuntary sterilization, by OHCHR et al (WHO, 2014).

Onapajo, Hakeem \& Christopher Isike, "The Global Politics of Gay Rights: The Straining Relations between the West and Africa" (2016) 6:1 Journal of Global Analysis 21-45. 
Ooi, Kee Beng, Arrested reform: the undoing of Abdullah Badawi (Kuala Lumpur, Malaysia: Research for Social Advancement, 2010).

Rajeswari, Indulekshmi, Same but different: a legal guidebook for LGBT couples \& families in Singapore (Singapore, 2017).

Saat, Norshahril, "The Implications of a Ma'ruf Amin Vice-Presidency in Indonesia" (2019) 20198.

—, "The UMNO-PAS Unity Charter and its Impact" (2019) 2019 ISEAS (Perspective) 4.

—, "Will PAS Governments in Kelantan and Terengganu Push for Islamic Laws?" (2018) 2018 ISEAS (Perspective) 2.

Sanders, Douglas, "Sex and Gender Diversity" (2016) 2 chapter 11 Southeast Asian Human Rights and Peace Studies Network (An Introduction to Human Rights in Southeast Asia), online: <https://www.academia.edu/43201788/Sex_and_Gender_ Diversity_in_Southeast_Asia $>$.

- "Sex and Gender Diversity" in Pavin Chachavalpongpun, ed, Routledge Handbook of Contemporary Thailand (Routledge \& CRC Press, 2020) 340.

__, "Thailand and 'Diverse Sexualities"” (2019) 20:1, Article 13 Australian Journal of Asian Law, online: <https://www.academia.edu/42675030/THAILAND _AND_DIVERSE_SEXUALITIES >.

—, "The Rainbow Lobby" in Peter A Jackson, ed, Queer Bangkok: Queer Asia (Hong Kong: Hong Kong Univ. Press, 2011) 229.

—, "What's Law Got to Do with It? Sex and Gender Diversity in East Asia" in Mark McLelland \& Vera Mackie, eds, Routledge Handbook of Sexuality Studies in East Asia (Routledge, 2014) 127.

Steiner, Kerstin, "Governing Islam: The State, the Administration of Muslim Law Act (AMLA) and Islam in Singapore” (2015) 16:1 Australian Journal of Asian Law 1 16.

Stiftung, Heinrich Boll, "Building Space for Lasting Change - LGBTI in Southeast Asia”, (30 January 2020), online: Southeast Asia Regional Office <https://th.boell.org/en/2020/01/30/building-space-lasting-change-lgbti-southeastasia>.

Tan, Beng Hui, Sexuality, Islam and Politics in Malaysia: A Study of the Shifting Strategies of Regulation Department of Southeast Asian Studies, National University of Singapore, 2012) [unpublished].

—, "The LGBT Quandary in New Malaysia" (2019) 20:1, article 15 Australian Journal of Asian Law, online: <https://papers.ssrn.com/abstract=3489659>. 
Trowell, Mark, The Prosecution of Anwar Ibrahim: The Final Play (Marshall Cavendish International (Asia) Private Limited, 2015).

United Nations, Born Free and Equal, Fact Sheet: Intersex (2015).

—, Born Free and Equal: Sexual Orientation, Gender Identity and Sex Characteristics in International Human Rights Law Second Edition, by United Nations (2019).

United Nations Development Program \& Sisters Foundation, Stories of Stigma: Exploring Stigma and Discrimination against Thai Transgender People while Accessing Health Care and in Other Settings, by United Nations Development Program \& Sisters Foundation (2020).

United Nations Office of the High Commissioner for Human Rights, Equal Eyes on Our World (2020).

United States Department of State, Bureau of Democracy, Human Rights and Labor, “2019 Country Reports on Human Rights Practices: Indonesia”, (2020), online: United States Department of State <https://www.state.gov/reports/2019-countryreports-on-human-rights-practices/indonesia/>.

Upchurch, Charles, Before Wilde: Sex Between Men in Britain's Age of Reform (University of California Press, 2009).

Vatanka, Alex, Iran and Pakistan: Security, Diplomacy and American Influence, reprint edition ed (London; New York: I.B. Tauris, 2015).

Wei, John, Queer Chinese Cultures and Mobilities: Kinship, Migration, and Middle Classes (Hong Kong: Hong Kong University Press, 2020).

Wieringa, Saskia E, "Criminalisation of Homosexuality in Indonesia: The Role of the Constitution and Civil Society” (2019) 20:1, article 17 Australian Journal of Asian Law, online: 〈https://papers.ssrn.com/abstract=3488561>.

Wintemute, Robert, Global Trends in Legal Recognition of Same-Sex Couples: Marriage, Registered Partnership, and Joint Parenting (Taipei, 2019).

Winter, Bronwyn, Maxime Forest \& Réjane Sénac, eds, Global Perspectives on SameSex Marriage (Palgrave Macmillan, 2018).

World Bank, "Economic Inclusion of LGBTI Groups in Thailand", (2018), online: World Bank <https://www.worldbank.org/en/country/thailand/publication/econ omic-inclusion-of-lgbti-groups-in-thailand>.

Yarcia, L E, T C de Vela \& M L Tan, "Queer Identity and Gender-Related Rights in Post-Colonial Philippines” (2019) 20:1, article 19 Australian Journal of Asian Law, online: $\langle$ https://papers.ssrn.com/abstract $=3488543>$.

Yulius, Hendri, Shawna Tang \& Baden Offord, “The Globalization of LGBT Identity and Same-Sex Marriage as a Catalyst of Neo-institutional Values: Singapore and 
Indonesia in Focus” in Bronwyn Winter, Maxime Forest \& Réjane Sénac, eds, Global Perspectives on Same-Sex Marriage (Palgrave Macmillan, 2018) 171.

Douglas Sanders is a Professor Emeritus from Faculty of Law, the University of British Columbia and Emeritus Visiting Professor, Faculty of Law, Chulalongkorn University, Bangkok. He is currently an academic associate at the Institute of Human Rights and Peace Studies, Mahidol University, Bangkok. He is a Canadian citizen, resident in Bangkok since 2003. 